Schwendel, Arved ORCID:

https://orcid.org/0000-0003-2937-1748, Nicholas, Andrew P., Aalto, Rolf E., Sambrook Smith, Greg H. and Buckley, Simon (2015) Interaction between meander dynamics and floodplain heterogeneity in a large tropical sand-bed river: the Rio Beni, Bolivian Amazon. Earth Surface Processes and Landforms, 40 (15). pp. 2026-2040.

Downloaded from: http://ray.yorksj.ac.uk/id/eprint/2620/

The version presented here may differ from the published version or version of record. If you intend to cite from the work you are advised to consult the publisher's version: https://doi.org/10.1002/esp.3777

Research at York St John (RaY) is an institutional repository. It supports the principles of open access by making the research outputs of the University available in digital form. Copyright of the items stored in RaY reside with the authors and/or other copyright owners. Users may access full text items free of charge, and may download a copy for private study or non-commercial research. For further reuse terms, see licence terms governing individual outputs. Institutional Repository Policy Statement

\title{
RaY
}

Research at the University of York St John

For more information please contact RaY at ray@yorksj.ac.uk 


\section{Earth Surface}

Processes and Landforms

\section{Interaction between meander dynamics and floodplain heterogeneity in a large tropical sand-bed river: the Rio Beni, Bolivian Amazon}

\begin{tabular}{|r|l|}
\hline Journal: & Earth Surface Processes and Landforms \\
\hline Manuscript ID: & ESP-14-0250.R3 \\
\hline Wiley - Manuscript type: & Paper \\
\hline Complete List of Authors: & $\begin{array}{l}\text { Schwendel, Arved; University of Exeter, College of Life and Environmental } \\
\text { Sciences } \\
\text { Nicholas, Andrew; University of Exeter, College of Life and Environmental } \\
\text { Sciences } \\
\text { Aalto, Rolf; University of Exeter, College of Life and Environmental } \\
\text { Sciences } \\
\text { Sambrook Smith, Greg; University of Birmingham, School of Geography, } \\
\text { Earth \& Environmental Sciences } \\
\text { Buckley, Simon; University of Exeter, College of Life and Environmental } \\
\text { Sciences }\end{array}$ \\
\hline Keywords: & $\begin{array}{l}\text { Meander migration, floodplain heterogeneity, bank erosion, numerical } \\
\text { model, planform evolution }\end{array}$ \\
\hline &
\end{tabular}


1 Interaction between meander dynamics and floodplain heterogeneity in a large

2 tropical sand-bed river: the Rio Beni, Bolivian Amazon

3 Schwendel A.C. ${ }^{1}$, Nicholas A.P. ${ }^{1}$, Aalto R.E. ${ }^{1}$, Sambrook Smith G.H. ${ }^{2}$, Buckley S. ${ }^{1}$

$4{ }^{1}$ College of Life and Environmental Sciences - Geography, University of Exeter,

5 Exeter, EX4 4RJ UK

$6{ }^{2}$ School of Geography, Earth \& Environmental Sciences, University of Birmingham,

$7 \quad$ Birmingham , B15 2TT, UK

8

\section{Abstract}

10 The evolution of meandering river floodplains is predominantly controlled by the

11 interplay between overbank sedimentation and channel migration. The resulting

12 spatial heterogeneity in floodplain deposits leads to variability in bank erodibility,

13 which in turn influences channel migration and planform development. Despite the

14 potential significance of these feedbacks, few studies have quantified their impact

15 upon channel evolution and floodplain construction in dynamic settings (e.g.,

16 locations characterized by rapid channel migration and high rates of overbank

17 sedimentation). This study employs a combination of field observations, GIS analysis

18 of satellite imagery and numerical modelling to investigate these issues along a 375

$19 \mathrm{~km}$ reach of the Rio Beni in the Bolivian Amazon. Results demonstrate that the

20 occurrence of clay-rich floodplain deposits promotes a significant reduction in

21 channel migration rates and distinctive styles of channel evolution, including channel

22 straightening and immobilisation of bend apices leading to channel narrowing. Clay

23 bodies act as stable locations limiting the propagation of planform disturbances in 
24 both upstream and downstream directions, and operate as 'hinge' points, around

25 which the channel migrates. Spatial variations in the erodibility of clay-rich floodplain

26 material also promote large-scale $(10-50 \mathrm{~km})$ differences in channel sinuosity and

27 migration, although these variables are also likely to be influenced by channel

28 gradient and tectonic effects that are difficult to quantify. Numerical model results

29 suggest that spatial heterogeneity in bank erodibility, driven by variable bank

30 composition, may force a substantial (c. 30\%) reduction in average channel

31 sinuosity, compared to situations in which bank strength is spatially homogeneous.

33 Keywords

34 Meander migration; floodplain heterogeneity; bank erosion; numerical model;

35 planform evolution 


\section{Introduction}

Understanding the relationship between meander migration and floodplain evolution is important for a wide range of issues, including river bank erosion and widening, supply of bedload and suspended sediment to the channel, and the associated deposition of sediment on in-channel bars and floodplain surfaces (Nanson and Hickin, 1986; Salo et al., 1986; Lauer and Parker, 2008). Moreover, these processes represent key controls on channel conveyance capacity, flood frequency, long-term floodplain morphodynamics and the ecological functioning of the channel-floodplain environment (Ward et al., 2002; Gueneralp et al., 2012). These issues are thus a primary concern in many areas of river management, including river restoration, floodplain land use and contamination, flood prevention and navigation.

The dynamics of meandering rivers has been the subject of intense research over the past four decades, from multiple perspectives. For example, many studies have attempted to classify channel behaviour (e.g., Brice, 1974; Hickin, 1974; Hooke, 1984; Hooke, 2003) and reproduce or explain it using mathematical models (e.g., Ikeda et al., 1981; Ferguson, 1984; Howard and Knutson, 1984; Johannesson and Parker, 1989; Howard, 1992; Zolezzi and Seminara, 2001). Migration of bends has often been explored with respect to freely-meandering rivers in relatively homogeneous floodplains, where characteristic planform patterns have been described (e.g., Hooke, 1995). Numerical models have been shown to be capable of generating realistic planform configurations (Lancaster and Bras, 2002; Camporeale et al., 2005; Frascati and Lanzoni, 2010), including compounding bends, asymmetric up-valley skewing and formation of multi-bend loops. However, understanding of the role of variability in bank strength as a control on meander migration remains incomplete. 
61 Variable resistance to erosion of river banks may be due to vegetation

62 (Perucca et al., 2007), slump blocks (Parker et al., 2011), drift wood, sedimentology and pedological evolution of bank sediments (Constantine et al., 2009), bedrock (Limaye and Lamb, 2014) or differences in bank height (van de Wiel and Darby, 2007; Xu et al., 2011). Numerous studies have investigated how such variations in bank strength impact on meander migration (e.g., Howard, 1996; Sun et al., 1996; Huang and Nanson, 1998; Hudson and Kesel, 2000; Seminara, 2006, Gueneralp and Rhoads, 2011; Motta et al., 2012a; Posner and Duan, 2012; Limaye and Lamb, 2014). However, the majority of this work has been based on numerical modelling rather than empirical evidence, due to the relatively short record of high quality imagery (e.g. c. 40 years in the case of satellite data) available for the study of channel migration at high temporal resolutions. Modelling studies suggest that a decrease in channel belt width may occur where bank erodibility is spatially heterogeneous (Sun et al., 1996; Gueneralp and Rhoads, 2011). However, the implications for meander geometry remain to be resolved fully. For example, Sun et al. (1996) found that floodplain heterogeneity has a limited impact on bend wavelength, while Gueneralp and Rhoads (2011) show that it may promote compound bends and downstream-skewing of meanders normally associated with super-resonant conditions (Camporeale and Ridolfi, 2006; Seminara, 2006). Huang and Nanson (1998) found an influence of variable bank strength on channel geometry, in particular width, but indicate that its impact is limited compared to hydraulic factors.

Significantly, several modelling studies have examined the effects of a random spatial distribution of floodplain erodibility (e.g., Gueneralp and Rhoads, 2011) or have employed a stochastic model in which mean erodibility decreases with 
86 distance from the channel (e.g., Motta et al., 2012a). These studies demonstrate the

87 scale-dependent influence of floodplain heterogeneity on channel planform

complexity. However, floodplain heterogeneity is unlikely to vary in a way that is

random, but is instead likely to be controlled by the spatial scaling of, and

interactions between, floodplain morphology, hydrodynamics, vegetation, and

sedimentation processes. Thus the role of sedimentary heterogeneity in floodplain

evolution and meander migration requires further research (Guneralp et al., 2012),

particularly in the context of the complexity found in natural landscapes.

The aim of this paper is to quantify the influence of variations in bank composition on meander migration within large, dynamic sand-bed rivers, using field and remote sensing datasets obtained from the Rio Beni in the Bolivian Amazon.

97 The specific objectives of the work are threefold: First, to assess the influence of bank material on rate and style of channel migration at individual meander bends.

Second, to examine channel evolution over multiple bends, in order to elucidate the role of floodplain heterogeneity as a control on large-scale channel belt characteristics and on the propagation of planform irregularities between bends.

Third, to explore the potential for simulating and explaining these characteristics using a simple numerical model of meander migration.

\section{Study site}

106 The Rio Beni was chosen for this study due to its extensive floodplain, which is essentially undisturbed by human influence, and its high rates of meander migration and floodplain sedimentation within a single active channel belt. The reach of the Rio 
110 Bolivia (Fig. 1), and has been largely unaffected by the effects of Holocene sea level

111

112

113

114

115

116

117

118

119

120

121

122

123

124

125

126

127

128

129

130

131

132

133

134 change. The upstream end of this reach is near Rurrenabaque, where the Beni

leaves the piedmont of the Andes (Serrania el Susi) and meanders for approximately

$375 \mathrm{~km}$ (channel length) through the forested 'Llanos de Mojos', a floodplain built up

of late-Miocene and Quaternary sediments (Dumont, 1996; Gautier et al., 2007).

Catchment area at Rurrenabaque is $68,000 \mathrm{~km}^{2}$ (Gautier et al., 2010), mean channel width at low flow is $430 \mathrm{~m}$, mean discharge is $2,300 \mathrm{~m}^{3} \mathrm{~s}^{-1}$, and annual flood peaks frequently exceed $20,000 \mathrm{~m}^{3} \mathrm{~s}^{-1}$ (Environmental Research Observatory (ORE) HyBAm). The Rio Beni transports a comparatively high sediment load of $219 \times 10^{6} \mathrm{t}$ $\mathrm{a}^{-1}$ (Latrubesse and Restrepo, 2014), which can be characterised as of fresh Andean origin (Guyot et al., 2007) and constitutes $72 \%$ of the load of the Rio Madeira (Guyot et al., 1999).

Water surface slope decreases dramatically within the upstream section of the study reach where the Rio Beni leaves the piedmont fan and bed material changes from cobble-gravel to sand. Downstream of this point, channel slope declines from 0.0002 to $0.00007 \mathrm{~m} \mathrm{~m}^{-1}$ over a distance of $300 \mathrm{~km}$. Beyond this (over the final 75 $\mathrm{km}$ ) the river profile steepens, although the paucity of reliable dGPS data make it difficult to quantify the gradient with confidence (see also Gautier et al., 2007). Mean channel sinuosity within the study reach varies temporally (between 1.8 and 2.0) and spatially amongst sub-reaches (between 1.3 and 2.7) (see also Dumont, 1996, Gautier et al., 2007). Downstream of the piedmont fan, median sediment size of bed and suspended load is relatively constant ranging between $0.09-0.15 \mathrm{~mm}$ and $0.0094-0.012 \mathrm{~mm}$ respectively (Guyot et al., 1999). The channel and its proximal floodplain are largely unaffected by anthropogenic modification such as bank protection, dredging or deforestation (Aalto et al., 2003). 
135 The Beni channel belt has experienced a counterclockwise shift from a

136 northeast orientation (a position currently occupied by the Rio Yacumu) to a more

137 northerly course during the Holocene (Plafker, 1964). Moreover, the deflection point

138 migrated northward following a north-striking fault line that separates old upper fluvial

139 terraces and hardened clay sediments in the NW from younger floodplain sediments

140 in the southeast (Dumont and Hannagarth, 1993; Dumont, 1996). The migration of

141 the channel belt also responds to differential subsidence and uplift patterns aligned

142 with southwest - northeast striking lineaments in the Brazilian Craton (Plafker, 1964;

143 Allenby, 1988).

144

145 Methods

146 Field data were acquired during visits to the study area between 2011 and 2013.

147 Data include measurements of water surface slope and ground elevation obtained

148 using dGPS (XRT, Trimble Navigation Ltd, Sunnyvale, USA) in conjunction with real-

149 time OmniSTAR HP correction or post-processing (CSRS-PrecisePointPositioning,

150 Natural Resources Canada, Ottawa, Canada). Relative bank height (the difference

151 between the bank top and low flow water level) was measured from a boat with a

152 dGPS supported laser range finder (Impulse 200 LR, Laser Technology Inc.,

153 Centennial, USA). These measurements were taken on cut bank and point bar sides

154 of bends and along straight sections in intervals of approximately $100 \mathrm{~m}$. Differences

155 in bank composition were mapped using digital photographs of bank sections along

156 approximately $350 \mathrm{~km}$ of channel combined with sampling of bank sediments $(\mathrm{n}=$

157 67) for laboratory grain size analysis, carried out using a Sedigraph 5100

158 (Micromeretics Instrument Corp., Norcross, USA). Bank material was sampled at a 
number of heights above the water level at representative locations for each bank material class.

Rates and styles of river migration were quantified by digitizing channel bank lines in ArcGIS (ESRI, Redlands, USA) from geo-referenced multispectral Landsat imagery (Table 1), taken during dry season (May to September), for 18 years between 1975 and 2011 (Gautier et al., 2007). Additional bank lines were acquired from aerial photography collected in 1960 (provided by the Bolivian Navy, see also Plafker, 1964) that covered the upper $280 \mathrm{~km}$ of the study reach (Table 1). Individual bends were numbered from the upstream end of the reach (117 bends in total). It should be noted that not all bends are present over the entire period of study (due to periodic bend initiation and abandonment). The study reach was divided into 19 subreaches (mean length $\sim 20 \mathrm{~km}$ ) at locations where the channel has experienced only minor lateral migration over the past 50 years (see Fig. 1).

Bank lines were converted to centrelines, which were then resampled to a node spacing of $100 \mathrm{~m}$ (approximately a quarter of one mean channel width) for use in subsequent analysis. Curvature was calculated following Motta et al. (2012b; equation 15), while migration rate at bends was measured as the area between two centrelines divided by the bend length, whereby bends are bounded in up- and downstream directions by points of inflection of the centreline. Apparent migration associated with centerline movement following bend cutoff has been excluded from all calculations. It should be noted that migration rates calculated from image pairs may be sensitive to the time period between images. For example, where the channel does not move in a consistent direction over time the migration rate from a single pair of images may be under-estimated (i.e. where the migration direction reverses during the period covered by the image pair). Between 2003 and 2011, 
184 errors introduced by image rectification were found to be negligible, due to precise 185 pre-rectification of the Landsat images. For older images, migration distances of less

than $16 \mathrm{~m}$ can be affected by image rectification errors (RMSE $<16 \mathrm{~m}$ relative to 2000 image; Table 1). The mean random error induced by pixel resolution $(30 \mathrm{~m})$ is expected to be close to zero over an entire bank line.

Bend evolution was investigated at 117 bends over a period of 51 years. This involved visual assessment of individual bends in ArcGIS and classification according to channel migration style (see Fig. 2; see also Hooke, 1984). Styles of migration include: a) longitudinal expansion or contraction of the bend (i.e., changes in bend wave length); b) lateral extension or contraction (i.e., changes in bend amplitude); c) confined or unconfined translation longitudinally up or down the valley; d) lateral displacement (bend migration without alteration of planform shape between points of inflection); e) bend rotation; and f) no change (stable). Complex, irregular and compounding patterns were separated from simple bend evolution styles. Some bends are characterised by mixed styles of migration involving several elements of the behaviour outlined above. Thus this classification results in numerous combinations of the basic types of channel change, which were then generalised and grouped into 7 common migration styles in order to remove some of the subjectivity introduced by the visual assessment. The focus of this classification is on dominant style of migration and not the quantification of the magnitude of displacement.

In order to explore the relationship between channel geometry, migration rate and bank erodibility further, numerical simulations were carried out using a simple model of meander migration and floodplain sedimentation. The approach adopted herein follows that of Howard (1992), differing only in the detail of the model formulation (see below). Specifically, we simulate overbank sedimentation using a 
209 form of exponential decay law, as is common in models of long-term floodplain

210 evolution (e.g., Howard, 1992; Mackey and Bridge, 1995):

211

$$
D_{i}=C_{i} H^{1.5} \mathrm{e}^{-\alpha_{i} x}
$$

212 where $D_{i}$ is the deposition rate for size fraction $i, C_{i}$ and $\alpha_{i}$ are a grain size dependent constant and decay coefficient, $H$ is the height difference between the floodplain surface and an assumed maximum flood water level, and $x$ is distance to the nearest channel. The non-linear dependence of $D$ upon $H$ reflects the increased frequency of inundation of low-lying floodplain areas. In the current model application, two grain size fractions have been used (one fine fraction and one coarse fraction). They are not intended to represent specific sediment sizes because the model should be considered phenomenological rather than physically-based. The parameters $C_{i}$ and $\alpha_{i}$ were assigned values of 0.035 and 0.0015 , respectively, for the coarse size fraction, and 0.005 and 0.00015 , respectively, for the fine size fraction. These values were selected to approximate the decline in sedimentation rates and deposit grain size observed for the Beni by Aalto et al. (2003). This equation is applied over a grid of cells to update the floodplain grain size composition (and topography) during each model iteration. Knutson (1984), implemented using the parameterization that is equivalent to the approach of Ikeda et al. (1981). In this model, migration rates are a product of the weighted sum of local and upstream channel curvatures, and a local bank erodibility coefficient. Thus the detail of flow and sediment transport are not represented and channel migration is a function of planform geometry and bank strength only. 
233

234

235

236

237

238

239

240

241

242

243

244

245

246

247

248

249

250

251

252

253

254

255

256

mean channel width along the centerline. Migration leads to movement of these

nodes and, ultimately, to neck cutoff (when two sections of channel migrate close to

one another). Chute cutoffs are not modelled herein, and are rare along the Beni.

Erodibility is defined as a function of the floodplain grain size composition in the grid

cell into which the channel is migrating. The relationship between bank erodibility $(E)$

and the fraction of the floodplain composed of fines $(F)$ is represented by:

$$
E=\beta\left(0.05+0.95(1-F)^{k}\right)
$$

where $\beta$ and $k$ are constants. The value of $\beta$ controls the average rate of channel migration, but not the dependence of migration on floodplain heterogeneity. The value of $k$ determines the strength of the relationship between erodibility and bank composition (a higher value of $k$ yields a stronger grain size dependence). The form of equation (2) was chosen by combining relationships between bank silt-clay content, critical shear stress, and bank erosion rate presented by Julian and Torres (2006; their Figures 4 and 6). They report an inverse relationship between critical shear stress and bank erosion rates, which would lead to infinite erosion rates where $F$ tends to 0 . Consequently, equation (2) is adopted herein, which overcomes this problem and provides a good fit to the relationships shown by Julian and Torres (2006) where $k=6$. The combined bank erosion and floodplain sedimentation model was implemented herein using $\beta=4$ and $k=6, \beta=2$ and $k=3$ (i.e. reduced dependence of $E$ on $F$ ), and $\beta=1$ and $k=0$ (i.e. bank erodibility independent of floodplain grain size composition). Simulations used a floodplain domain with dimensions of $125 \mathrm{~km}$ (downstream) by $50 \mathrm{~km}$ (cross-stream) and a grid resolution of $500 \mathrm{~m}$. The model is initialized using a flat floodplain and straight channel with very small random perturbations in channel centerline coordinates. 


\section{Results}

258 Rates and styles of migration at individual bends

259 Cutbanks characterised by clay-rich sediments (hereafter also termed clay banks)

260 were mapped at 19 bends during several field visits between 2003 and 2011. Such

261 banks were identified by their grain size assemblage and their distinctive colour and

262 geometry. For example, clay-rich banks often contain ferrous concretions, giving

263 them a speckled appearance, while on the lower bank the matrix material is often of

264 a greyish colour, indicating oxygen depletion over prolonged periods (see Fig. 3).

265 The coherent nature of these banks leads to a stable, often slightly less than vertical

266 upper bank geometry, below which banks can have a scalloped shape with regular

267 protrusions into the channel. The average grain size composition of banks identified

268 visually as clay-rich was found to be $39-84 \%$ clay and $15-61 \%$ silt, compared with

$26915-25 \%$ clay and $75-83 \%$ silt in other bank sections. Sand constitutes a small

270 fraction in most banks with a range of $0-11 \%$. The $D_{50}$ of bank material classified as

271 clay-rich ranges between $<0.6$ and $3.42 \mu \mathrm{m}$ but is typically smaller than $2 \mu \mathrm{m}$.

272 Although clay banks are unusually high in some places (e.g., due to tectonic uplift at

273 the upstream end of the study site, in sub-reach 1) their mean height above low flow

274 water level over the entire study reach $(6.47 \mathrm{~m})$ is not significantly higher than for

275 banks composed of any other substrate $(6.40 \mathrm{~m})$ (two-sample t test, $\alpha=0.05$ ).

276 Moreover, there is no significant relationship between migration rate and bank height

277 evident within the study reach as a whole (Pearson's $r=-0.24, p=0.067, n=61$ ).

278 Individual clay-rich banks vary in grain size, extent of reddish concretions,

279 height and erodibility, which may reflect differences in their age and post-

280 depositional development. Despite this variability, locations occupied by clay banks 
281 experience significantly lower mean rates of channel migration at the scale of whole

282

283

284

285

286

287

288

289

290

291

292

293

294

295

296

297

298

299

300

301

302

303

304

305 bends (two-sample t test, $p<0.05$ ) compared to bends with cutbanks made of any other alluvial deposit (Fig. 4). Mean annual bend migration rate of individual bends ranges between $3.4 \mathrm{ma}^{-1}$ and $530.7 \mathrm{ma}^{-1}$. It is lowest at bends with clay banks $(23.8$ $\left.\mathrm{ma}^{-1}\right)$, followed by bends migrating into mixed substrates $\left(37.3 \mathrm{ma}^{-1}\right)$, point bar deposits $\left(43.3 \mathrm{ma}^{-1}\right)$ and infilled channels $\left(58.8 \mathrm{ma}^{-1}\right)$. Mean migration rate is highest at bends migrating into oxbow lakes $\left(98.8 \mathrm{ma}^{-1}\right)$, although migration rates are highly variable in such cases and depend on cutoff age (degree of fill), substrate (erodibility) and angle of approach by the migrating bend. Mean annual bend migration rates show a significant correlation $(\alpha=0.05)$ with a number of discharge metrics such as accumulated discharge during wet seasons (December to April), maximum annual discharge and the number of days with discharge in excess of bankfull $\left(6000 \mathrm{~m}^{3} \mathrm{~s}^{-1}\right)$ with Pearson's $r$ of $0.66,0.71$ and 0.82 , respectively.

Correlations based on metrics that summarise the previous three wet seasons are stronger than those based on the previous wet season only.

The channel in the region of clay banks is characterised by distinct narrowing just downstream of the apex, often due to a resistant notch of clay protruding into the channel (average channel width of $290 \mathrm{~m}$ in 2011, for $\mathrm{n}=22$ bends). Channel width at the equivalent position for bends without clay banks is $534 m(n=63)$. Despite the particular planform configuration at these bends, no specific pattern in water surface slope could be established. Bend migration rate is not correlated to mean slope at various distances upstream of, downstream of, or around bend apices.

Classification of bend migration style (over the period from 1960 to 2011) indicates that $28.1 \%$ of the bends are relatively immobile, as indicated by their low mean rate of migration $\left(26.0 \mathrm{ma}^{-1}\right)$. Sub-reaches dominated by clay-rich banks 
306 (especially sub-reaches 1 and 12, Fig. 5) are characterised by a high proportion of 307 immobile bends. Wavelength expansion is apparent at $13.3 \%$ of bends, often in 308 combination with bend rotation and/or changes in amplitude. This occurs mainly in 309 the more mobile sub-reaches located in the central part of the study reach. In contrast $16.8 \%$ of bends experienced a reduction in wavelength, often accompanied by lateral extension (e.g., a common style in the early phase of bend development, 312 just after bend inception) and/or rotation, but, in a few cases, also by a reduction in 313 bend amplitude.

Channel belt widening, as signified by the bend extension and lateral displacement without a change in bend shape, occurs at $30.1 \%$ of bends, and is typical of mobile sub-reaches with few clay-rich banks (e.g., sub-reaches $6,9,10,13,16)$. Bend rotation is also prominent in these sub-reaches $(11.1 \%$ of bends) and takes place more frequently in a downstream direction. Translation is experienced by $14.8 \%$ of bends, is most significant in sub-reaches $2,4,8$ and 14 , and is not preferentially associated with particular bank composition. Up-valley bend translation is rare and occurs mainly at a slow rate and is often associated with migration along a clay-rich bank. A small proportion (2.1\%) of all bends showed signs of compounding and increased complexity. Compound bend development occurs in slowly expanding meanders (e.g., in sub-reach 17), as a result of flow diversion at bifurcations (e.g., in sub-reach 4) or partial contact with a clay body (e.g., in sub-reach 8).

Bends with clay-rich banks may share common planform and evolutionary characteristics, depending on the precise location of clay bodies. For example, migration of the apex of a bend into a clay body can lead to wavelength expansion, eventually followed by compounding (Fig. 2a). In the upstream part of the study reach the active channel belt appears to be confined by elongated clay bodies 
331 parallel to the valley axis. In this region, the entire active cutbank of some bends

332

333

334

335

336

337 consists of clay-rich deposits, which usually render the bend immobile with limited

up- or down-valley translation (e.g., bend 13 up-valley, Fig. 6). In such cases, some

upstream rotation of the bend around the apex may occur. The downstream limb of

bends with clay-rich banks tends to elongate and straighten with time. Since

meanders not constricted by clay-rich banks typically have shorter life spans (i.e.

they evolve to cutoff more quickly), and higher rates of migration and down-valley

translation, bends located upstream of less mobile clay-rich meanders can appear to

move down-valley past the relative fixed apices of clay banks. As a result, bends

with clay-rich banks often appear in planform to be skewed up-valley, with the

downstream limb being laterally immobilised by contact with the clay-rich bank (e.g.,

bend 14 in Fig. 6). Consequently, over time, bends with clay-rich banks can

experience a reduction in wave length due to faster migration of the more mobile

upstream limb than of the downstream limb, which eventually leads to a neck cutoff.

\section{Planform evolution at multi-bend scales}

Downstream of clay banks the channel planform often exhibits straightening unless influenced by contact with other clay bodies (Fig. 7). This process involves a gradual reduction in sinuosity over several years, in contrast to rapid channel shortening due

to bend cutoff. Channel straightening usually involves an increase in wavelength and contraction in amplitude of bends, for example confined downstream translation, when the downstream limb of a bend translates faster down-valley than the upstream limb (as visible in sub-reaches 1, 8, 10, 12). Such straightening downstream of bends with clay-rich banks may be terminated when the bend in 
355 question is cutoff. The steady lengthening of straight reaches can be accelerated by cutoffs, or slowed down or reversed where the channel that is straightening migrates into another clay body (dashed lines in Fig. 7), which introduces new bends and thus increases sinuosity. Moreover, in locations characterised by many closely spaced clay bodies, straights may be unable to form, and cutoffs may be frequent (e.g. subreaches 4 and 6). Sustained channel straightening over distances greater than 10 $\mathrm{km}$ and periods longer than 10 years is rare and only found in sub-reaches 7 and 15 in the last 50 years. For example, in the latter sub-reach, sinuosity declined from 1.31 to 1.24 over a 15 year period follow a cutoff in 1960 . This process appears to have been induced by contact with the clay body on the western edge of the channel belt. More recently, the channel in sub-reach 7 (see Fig. 8) was characterised by channel and a clay body in bend 35 at the upstream end of the sub-reach (Fig. 8 a, b) as early as 1987 . This triggered a series of neck cutoffs at bends 36 and 39 ( Fig. $8 \mathrm{~b}$ and $8 \mathrm{c}$ ), accelerated bend migration down-valley, rapid planform adjustment via chute cutoffs at bends 41 and 43 (Fig. 8 d) and thus significant lengthening of the straight reach below bend 35 until 2005 (Fig. 8 e; see also Fig. 7). Although new planform perturbations developed upstream of former bend 39, the downstream translation of these perturbations has been impeded by a clay-rich bank at bend 40 ,

377 which acts as a hinge with a fixed apex, thus limiting channel adjustment

378 downstream (Fig. 8 e and 8 f). Consequently, the newly formed bend 38 has 379 increased in amplitude and become gradually more asymmetric due to stablisation of 
380 the apex of bend 40 , leading to a steady increase in sinuosity since 2005 . The

381

382

383

384

385

386

387

388

389

390

391

392

393

394

395

396

397

398

399

400

401

402

403

404 overall tendency for clay-rich banks to induce channel straightening leads to an

abundance of channel sections with low planform curvature. Moreover, the

frequency distribution of channel curvature for sub-reaches with numerous clay bank

sections exhibits a distinct exponential form, compared to a more linear distribution

in other sub-reaches (Fig. 9).

The previous sections have highlighted the influence of clay banks on channel

form at the scale of individual bends and sub-reaches (lengths of c. $20 \mathrm{~km}$ ). Spatial

variations in the frequency of clay bodies along the $375 \mathrm{~km}$ study reach also appear

to promote changes in channel dynamics at larger spatial scales, both in terms of

rates of bend migration and cutoff (Fig. 10) and channel sinuosity (Fig. 11). For

example, in the upper part of the study reach (sub-reaches 1 to 5 and the upstream

part of sub-reach 6) the active channel belt is laterally confined by clay bodies

(elements of the Chore and Caupolican complexes in the northwest, and the Ichilo

complex in the southeast; GEOBOL, 1979). Consequently, channel sinuosity is low

in general (<2 in most sub-reaches) and the upper end of this zone in particular has

experienced low migration rates $\left(<5 \mathrm{ma}^{-1}\right.$ in large areas). Further north, the western

side of the active channel belt is also bounded by clay bodies of the Ixiamas

complex, while in the east relatively few clay contacts were found. In this area, sub-

reaches 12 and 15 are strongly influenced by clay banks and exhibit a combination

of low migration rates $\left(<20 \mathrm{ma}^{-1}\right)$ and low sinuosity $(<2)$. In contrast, in sub-reaches

where meandering is relatively unconstrained (e.g., sub-reach $6,9,10,14,16$ )

migration rates are higher (27.0 $\mathrm{ma}^{-1}$ on average), cutoffs are frequent (Fig. 10) and

sinuosity is high (2.24 on average). Indeed, the transition between reaches in which

confining clay bodies are common and absent can be associated with a marked 
405 change in channel planform character. For example, in sub-reach 6 downstream of

406 bend 25 the channel leaves a zone where clay banks provide a strong stabilising

407 influence. As a result, sinuosity increases and the channel belt widens, promoting

408 rapid bend migration, increased cutoff frequency, rotation of bends, and the

409 formation and cutoff of a multi-loop bend (Fig. 12). However, along the central

410 section of the study reach, downstream propagation of this dynamic channel

411 behaviour is prevented by the contact with the clay banks located further

412 downstream (e.g. bend 35, Fig. 8).

413

$414 \quad$ Numerical modelling

415 The numerical model described above was applied to investigate the relationship

416 between heterogeneity in bank erodibility and planform channel characteristics

417 further. Model simulations were run for a period sufficient for the channel to develop

418 a statistically steady form (i.e. without a long-term trend in channel sinuosity) and to

419 rework the floodplain multiple times (8000 model iterations). Figure 13 shows the

420 time series of channel sinuosity for model runs with contrasting $k$ values. All

421 simulations show a rapid initial increase in sinuosity as a meandering channel

422 develops, as described by others (e.g., Howard and Knutson, 1984; Howard, 1992).

423 Subsequently, sinuosity declines (following the first cutoff events) and then oscillates

424 (reflecting the balance between channel lengthening, due to migration, and

425 shortening, due to cutoffs). Figure 13 illustrates that spatial variability in erodibility

426 (due to floodplain heterogeneity) promotes a substantial reduction in channel

427 sinuosity. Moreover, simulation results are relatively insensitive to the precise value

428 of $k$ (for $k \geq 3$ ). For example, in the latter half of the simulation following the model 
429 spin-up phase, mean sinuosity is $2.87(k=0), 2.05(k=3)$, and $2.07(k=6)$. Figure

43014 , shows that frequency distributions of channel curvature differ between

431 simulations that neglect $(k=0)$ and account for floodplain heterogeneity $(k=3$; note

432 that the distribution for $k=6$ is very similar). More specifically, spatial variability in

433 heterogeneity promotes a curvature distribution similar to that observed on the Beni

434 in sub-reaches where clay-rich banks are common, while neglecting spatial

435 variability in erodibility leads to a distribution more similar to reaches along the Beni

436 where clay banks are uncommon (Fig. 9).

Figure 15 shows the simulated planform pattern of floodplain sediment

438 heterogeneity after 3900 iterations and the meandering channel position (at two

439 instants in time) during model runs with constant bank erodibility $(k=0)$ and bank

440 erodibility dependent on grain size assemblage $(k=3)$. It is evident from these plots

441 that spatial variability in bank erodibility leads to a reduction in active channel belt

442 width (by c. $35 \%$ on average), meander migration rates (by c. $40 \%$ ) and cutoff

443 frequency (by c. 50\%), where the latter is indicated in Figure 15 by the number of

444 abandoned channels that are characterised by a high proportion of fine sediment.

445 Moreover, simulations in which bank erosion is dependent on floodplain grain size

446 composition show several of the features of channel migration observed along the

447 Rio Beni. These include the development of angular bend configurations,

448 compounding, straightening downstream of contacts with fine sediment deposits and

449 a tendency for the channel to become relatively immobile at locations where bank

450 sediment is fine.

451

452 Discussion 
453 The results presented above demonstrate that the spatial distribution of clay-rich

454 sediments within the floodplain of the Rio Beni exerts a significant influence on rates

455 of bank erosion, styles of meander migration, and channel morphology at bend and

456 channel-belt scales. The influence of floodplain heterogeneity on channel migration

457 has been recognised in many previous studies (e.g. Howard, 1996; Sun et al., 1996;

458 Huang and Nanson, 1998; Hudson and Kesel, 2000; Seminara, 2006, Gueneralp

459 and Rhoads, 2011; Motta et al., 2012a; Posner and Duan, 2012; Limaye and Lamb,

460 2014). However, the controls on and causes of heterogenities in bank erodibility

461 remain to be understood fully. Several studies have focused on the influence on

462 channel migration of resistant clay plugs formed in oxbox lakes (e.g. Howard, 1996;

463 Sun et al., 1996; Hudson and Kesel, 2000). Similarly, it is in such locations that

464 resistance to erosion is highest in the simple numerical model utilised here. In

465 contrast, rates of bank erosion into channel cutoff sites are some of the most rapid

466 observed in this study (c. $140 \mathrm{ma}^{-1}$ on average). This probably reflects the young age

467 of these cutoffs, which means that they have yet to be filled completely and the

468 sediment within them has not been consolidated or altered by pedogenic processes

469 (see also Gautier, 2007). The grain size of clay-rich banks is similar to that of

470 deposits found near the outlet of an oxbow lake $\left(D_{50}: 1.5-3.0 \mu \mathrm{m}\right.$; Gautier et al.,

471 2010), which is a typical environment for the formation of clay plugs, although oxbow

472 lake deposits can be highly heterogeneous.

473 Overall, we find no consistent association between clay-rich bank material

474 and former channel locations along the Rio Beni, hence the origin of some of the

475 resistant bank sediments observed here remains uncertain. Moreover, previous

476 studies of channel migration along the Rio Beni that have investigated oxbow fill

477 processes provide no insight into the question of the evolution of resistant clay 
478 bodies (e.g. Gautier et al., 2007; 2010). The clay-rich bank sediments observed 479 along the Beni may have a range of origins, including fine-grained sedimentation 480 within floodplain depressions, distal floodbasins, bar-top chute channels or remnants 481 of mainstem cutoff infills (Fisk, 1947; Kolb, 1975; Schumm and Spitz, 1996). Image 482 analysis confirms that clay bodies identified in bank sections have not been 483 reworked since 1960, and that in many places the time since deposition of these 484 sediments is likely to be much longer, although they may include a surface drape of 485 more recent deposition. Clay-rich material with a similar mottled appearance (see 486 Fig. 3a) was identified in floodplain sediments sampled in back swamp areas to the 487 west of the Rio Beni and in older channel belts that are likely to have experienced 488 slow sedimentation (perhaps $<1 \mathrm{~mm}$ a ${ }^{-1}$, based on ${ }^{210} \mathrm{~Pb}$ measurements from 489 floodplain cores) over a prolonged time period (Aalto et al., 2003; Dumont, 1996). 490 Based on these observations, we speculate that deposit age may be an important 491 control on the properties and erodibility of these sediments, and that the resistant bank sediments observed here are likely hundreds to thousands of years old, and may thus be the product of prolonged sedimentation in distal floodbasins. Our analysis suggests that the presence or absence of clay-rich bank sediment is the dominant spatial control on bank erosion rates along the Rio Beni.

496 The resulting erosion rates are $60 \%$ and $48 \%$ of those of coarser pointbar and channel deposits, while rates of bend migration into oxbow lakes are much greater and highly variable. The measured mean migration rates over many bends agree well with those of Gautier et al. (2007) for the same reach of the Beni although sub500 division of bends into different sub-reaches prohibits direct comparison. Bank erosion rates were found to be unrelated to cutbank height or slope in the vicinity of the bend. Moreover, the relationship between mean bend curvature and migration 
503 rate differs markedly between bends with and without clay-rich banks. For example,

504 at the former sites, migration rates are generally low over a wide range of curvatures

505 and thus largely independent of curvature. In the absence of clay rich banks,

506 migration rate is maximized at intermediate bend curvatures, as observed previously

507 for many freely meandering rivers (Nanson and Hickin, 1983; Hooke, 1997; Crosato,

508 2009). Temporally, mean annual bend migration rates are related to flood

509 magnitude, intensity and duration, as previously found by Gautier et al. (2007) on the

510 same river reach. However, we find that discharge metrics based on the previous

511 three wet seasons are better predictors of bank erosion rates than discharge metrics

512 based on a single wet season.

513 Channel morphology and styles of bend migration in the presence of clay-rich

514 deposits along the Rio Beni differ from the predictions of existing theory and simple

515 conceptual models, but are consistent with some past observations of channel

516 behaviour. For example, where the apex and the downstream limb of a bend is in

517 contact with a clay-rich bank, faster down-valley translation of the more mobile

518 upstream limb leads to a reduction in wave length, up-valley skewing (e.g. bend 24

519 in Fig. 12), and eventually to neck cutoff. Similar processes have been described

520 previously for the Mississippi River (Fisk, 1947). The observed decrease in channel

521 width downstream of the bend apex, where the channel is immobilised by resistant

522 banks, contrasts with the peak in width at this location that has been associated with

523 'free-meandering bends' (Luchi et al., 2011; Zolezzi et al., 2012). However, this

524 difference in channel morphology is consistent with the difference in boundary

525 conditions, and serves to emphasize the significant control exerted by variable bank

526 strength. Overall, fewer than $10 \%$ of bends are characterised by styles of

527 development that fit simple conceptual models of bend evolution (Hickin, 1978; 
528 Hooke, 1987) and associated changes in migration rate between inception and cutoff 529 (Hooke and Yorke, 2010). This can be attributed, in part, to the influence of 530 heterogeneity in floodplain composition on bend migration and planform shape. For 531 example, during a period of straightening in sub-reach 7 downstream of the clay 532 contact in bend 35 a number of cutoffs occurred (Fig. 8) but instead of a gradual 533 increase in sinuosity, as predicted by conceptual models (Hooke, 2003), the reach 534 continued to straighten until 2005. Such cutoff avalanches are typical for meandering 535 rivers and have been observed along the Beni (Gautier et al., 2007) and elsewhere 536 (Stolum, 1996; Hooke, 2004), but the concurrent medium-term straightening is less 537 common.

In general, there appears to be an inverse relationship between clay body frequency and mean annual migration rate and channel sinuosity, which is related to

540 the role of clay banks in reducing bank erosion and promoting channel straightening.

541 However, this tendency over-simplifies the relationship between clay body frequency 542 and channel dynamics. For example, sub-reach 8 is characterised by very low 543 sinuosity and migration rates despite a lack of contact with clay-rich bank sections.

544 More generally, although migration rates at clay banks tend to be low, average rates 545 within sub-reaches where clay-banks are common need not necessarily be low if 546 migration rates between these immobile locations are enhanced. Figure 16 shows 547 that in sub-reaches 1 to 8 the apices of bends where clay-rich banks have been 548 found in 2011 have not moved significantly over up to five decades, and that channel 549 migration occurs only between these bends. Thus, bends with resistant clay-rich 550 banks can act as fixed hinges around which the channel migrates. Even where 551 cutoffs occur immediately upstream of these fixed points this has relatively little 552 impact on the position of these bends, and usually results in only short-term and 
553 limited bend translation (e.g., for 3 years at bend 18, Fig. 12a). Since planform

554 adjustment downstream of cutoffs is suppressed, new bends formed at the cutoff

555 tend to lengthen and extend rapidly (e.g., bends 16 and 20 in Figs. $6 \mathrm{c}$ and 12c).

556 When bends with clay-rich banks are cut off, this can result in a short-term increase

557 in migration rate and can lead to a change in migration direction into substrate of

558 different erodibility, thereby further increasing mobility (e.g., downstream of bend 43

559 after 2003, see Fig. 8e, f). Consequently, floodplain heterogeneity may also modify

560 the characteristic dynamics of channel evolution by promoting long periods of

561 stability punctuated by rapid channel adjustment when the influence of clay-rich

562 banks is temporarily removed. Moreover, the straight channels found downstream of

563 clay-rich bends may decouple these bends from planform evolution downstream if

564 the spacing between clay-rich bends is sufficient (e.g. between bend 20 and 24, but

565 not below bend 24 (Fig. 12d)).

566 Channel behaviour in sub-reaches 11 and 17 to 19 deviates from the

567 relationships identified above. For example, there are few clay bodies exposed along

568 channel bank lines in these areas, they are relatively stable (migration rates $<20 \mathrm{ma}^{-}$

$569^{1}$ ), and yet are characterised by relatively high sinuosity (Fig. 11). Sub-reaches 17 to

57019 lie towards the downstream end of the Beni foredeep, hence channel evolution in

571 this area is likely controlled in part by tectonics. For example, downstream of the

572 study reach the channel is bounded by higher terraces that are indicative of vertical

573 displacement of the channel bed relative to the surrounding floodplain. Gautier et al.

574 (2007) emphasize the role of tectonics in promoting low slopes and channel incision,

575 which in turn leads to lateral channel stability downstream of the junction between

576 the Rio Beni and the Rio Madidi. It is possible that these effects extend further

577 upstream beyond the junction with the Madidi into the study site considered here. 
578 However, the limited dGPS data that we obtained in this area indicate a steepening

579 of the channel water surface upstream of the Madidi. Moreover, channel stability in

580 sub-reaches 17 to 19 over the past few decades is not necessarily representative of

581 longer-term channel evolution, and the floodplain in this area contains ample

582 evidence of previous channel migration, abandonment and bifurcation.

583 The model results presented here illustrate that the simulation model captures

584 many of the effects of spatial variability in bank erodibility, despite the simplicity of

585 the process parameterisations used. Moreover, they support the conclusion that

586 floodplain heterogeneity may have a substantial influence on channel geometry and

587 styles of bend evolution. These results are consistent with those of previous

588 modelling studies that have highlighted the effects of heterogeneity in bank strength

589 on channel belt width (Sun et al., 1996) and meander dynamics (Gueneralp and

590 Rhoads, 2011). However, the current simulations also suggest that heterogeneity in

591 floodplain alluvium can promote a substantial reduction in channel sinuosity, which

592 would in turn have significant implications for channel gradient, flow conveyance,

593 sediment transport and, potentially, basin accommodation space. The differences in

594 channel behaviour simulated by these models likely reflects several factors, including

595 differences in the underlying meander migration models used, their parameterisation

596 of bank erodibility, and their ability to simulate spatial structure in floodplain

597 heterogeneity. As a consequence of this, the true sensitivity of channel behaviour to

598 heterogeneity in bank composition is difficult to quantify accurately using these

599 models, due to their phenomenological nature. Resolving this issue likely requires

600 the use of models with a stronger physical basis. Specifically, such models should:

601 (i) incorporate a physically-based (and perhaps fully three-dimensional) treatment of

602 hydrodynamics that is suitable for representing the controls on boundary shear 
603 stress in channels with complex planform geometries; (ii) be capable of representing

604 streamwise variations in channel width and depth linked to pinning of bend apices by

605 resistant floodplain sediments; (iii) include an improved treatment of floodplain

606 sediment conveyance and sedimentation, and the physical and chemical processes

607 that control the long-term evolution of floodplain sediment properties and erodibility.

608 Development of such a model represents a significant challenge because the nature

609 of and controls on long-term post-depositional changes in floodplain sediment

610 properties are poorly understood. Moreover, requirements (i) and (iii) are, to some

611 extent, mutually exclusive in that they may require the application of computationally

612 expensive hydrodynamic models over periods of millennia.

\section{Conclusions}

615 Many previous studies have hypothesized that spatial heterogeneity in floodplain

616 sediments and associated bank erodibility may represent an important control on the 617 evolution of alluvial meanders. This study has quantified these effects for the case of 618 the Rio Beni, Bolivia, which is a large dynamic sand-bed river, characterised by high 619 average rates of channel migration and overbank sedimentation. Field data and GIS 620 analysis demonstrate that floodplain clay bodies along the Rio Beni are a key control 621 on meander form and evolution at spatial scales ranging from individual bends up to 622 distances of several tens of kilometers. While the origin of these clay deposits is not 623 certain, we find no simple association between recent cutoff channels and the 624 location of clay bodies. Rather, we speculate that clay rich bodies may be a product 625 of slow sedimentation in distal flood basins, and that pedogenic processes may be 626 an important control on the long-term evolution of floodplain erodibility. 
627 Bends that interact with such clay bodies are associated with a significant

628 reduction in migration rate and channel width, and a change in the frequency

629 distribution of local channel curvature that is linked to the formation of more angular

630 geometries characterised by sharp bends and extended straight channel segments.

631 At larger spatial scales, clay bodies act as hinge points that can limit the upstream

632 and downstream propagation of morphodynamic perturbations (e.g., bend translation

633 and response to cutoff). As a consequence, the spatial distribution of clay bodies can

634 promote marked streamwise changes in meander sinuosity and dynamics (over

635 distances of $10-50 \mathrm{~km})$.

636 Our numerical model results are consistent with field observations, and imply

637 that spatial heterogeneity in bank erodibility driven by variable bank composition may

638 drive a substantial (c. $30 \%$ ) reduction in average channel sinuosity, compared to

639 situations in which bank strength is spatially homogeneous. Moreover, this effect is

640 not simply a consequence of a reduction in average bank erodibility. Rather, reduced

641 channel migration rates and sinuosity are driven, in part, by the change in the

642 curvature distribution of the channel. Thus, the increase in the length of straight

643 channel segments and the creation of sharp bends near clay bodies may both

644 influence the streamwise development of secondary flows and reduce rates of bank

645 erosion. Although the simple modelling framework employed does not represent flow

646 hydrodynamics or sediment transport processes, it does appear to provide a first

647 order representation of the link between floodplain erodibility and meander geometry

648 that supports this conclusion.

649 These results illustrate that heterogeneity in floodplain sedimentology is a first

650 order control on channel planform and dynamics. Moreover, by controlling channel

651 belt width, lateral channel migration and levee reworking, floodplain heterogeneity is 
652 likely an important influence on the geometry and rate of aggradation of alluvial 653 ridges, the frequency of avulsions and the resulting basin alluvial architecture. Since

654 the spatial-scaling of floodplain heterogeneity is linked to the processes (and 655 associated scales) that control floodplain construction, these effects cannot be 656 accounted for fully in numerical models using stochastically-generated patterns of 657 floodplain erodibility. Rather, attempts to model and thus understand meander 658 dynamics, even over relatively short time scales (e.g., 10-100 years), may need to 659 simulate time periods that are long enough to represent the evolution of floodplain 660 heterogeneity and the bi-directional feedbacks with channel morphodynamics.

\section{1}

\section{Acknowledgements}

663 This research was funded by the UK Natural Environment Research Council (grant $664 \mathrm{NE} / \mathrm{H} 009108 / 1)$. We are grateful to the two referees, whose comments led to 665 improvements in the manuscript. 


\section{References}

668 Aalto R, Maurice-Bourgoin L, Dunne T, Montgomery DR, Nittrouer CA, Guyot JL. 669 2003. Episodic sediment accumulation on Amazonian flood plains influenced 670 by El Nino/Southern Oscillation. Nature 425: 493-497.

671 Allenby RJ. 1988. Origin of rectangular and aligned lakes in the Beni Basin of 672 Bolivia. Tectonophysics 145: 1-20.

673 Brice JC. 1974. Evolution of meander loops. Geological Society of America Bulletin $674 \quad$ 85: $581-586$.

675 Camporeale C, Perona P, Porporato A, Ridolfi L. 2005. On the long-term behavior of 676 meandering rivers. Water Resources Research 41: W12403.

677 Camporeale C, Ridolfi L. 2006. Convective nature of the planimetric instability in 678 meandering river dynamics. Physical Review E 73: 026311.

Constantine CR, Dunne T, Hanson GJ. 2009. Examining the physical meaning of the bank erosion coefficient used in meander migration modeling. Geomorphology 106: 242-252.

Crosato A. 2009. Physical explanations in river meander migration rates from model comparison. Earth Surface Processes and Landforms 34: 2078-2086.

Dumont JF. 1996. Neotectonics of the Subandes-Brazilian craton boundary using geomorphological data: The Maranon and Beni basins. Tectonophysics 259: 137-151.

Dumont JF, Hannagarth W. 1993. River shifting and tectonics in the Beni basin. Third International Conference Geomorphology, Hamilton.

Ferguson RI. 1984. Kinematic model of meander migration. In River meandering, Elliot CM (ed.). ASCE: New York; 942-951. 
691 Fisk HN. 1947. Fine-grained alluvial deposits and their effects on Mississippi River

692

693

694

695

696

697

698

699

700

701

702

703

704

705

706

707

708

709

710

711

712

713 activity. USCE Mississippi River Communications 1: 82.

Frascati A, Lanzoni S. 2010. Long-term river meandering as a part of chaotic dynamics? A contribution from mathematical modelling. Earth Surface Processes and Landforms 35: 791-802.

Gautier E, Brunstein D, Vauchel P, Jouanneau J-M, Roulet M, Garcia C, Guyot JL, Castro M. 2010. Channel and floodplain sediment dynamics in a reach of the tropical meandering Rio Beni (Bolivian Amazonia). Earth Surface Processes and Landforms 35: 1838-1853.

Gautier E, Brunstein D, Vauchel P, Roulet M, Fuertes O, Guyot JL, Darozzes J, Bourrel L. 2007. Temporal relations between meander deformation, water discharge and sediment fluxes in the floodplain of the Rio Beni (Bolivian Amazonia). Earth Surface Processes and Landforms 32: 230-248.

GEOBOL. 1979. Complejos de Tierra del Oriente Boliviano. In ERTS, Brockmann CE (ed.). Servicio Geologico de Bolivia: La Paz.

Gueneralp I, Abad JD, Zolezzi G, Hooke J. 2012. Advances and challenges in meandering channels research. Geomorphology 163-164: 1-9.

Gueneralp I, Marston RA. 2012. Process-form linkages in meander morphodynamics: Bridging theoretical modeling and real world complexity. Progress in Physical Geography 36: 718-746.

Gueneralp I, Rhoads BL. 2011. Influence of floodplain erosional heterogeneity on planform complexity of meandering rivers. Geophysical Research Letters 38: L14401. 
714 Guyot JL, Jouanneau JM, Wasson JG. 1999. Characterisation of river bed and 715 suspended sediments in the Rio Madeira drainage basin (Bolivian Amazonia). Journal of South American Earth Sciences 12: 401-410.

717

718

719

720

721

722

723

724

725

726

727

728

729

730

731

732

733

734

735

736
Guyot JL, Jouanneau JM, Soares L, Boaventura GR, Maillet N, Lagane C. 2007. Clay mineral composition of river sediments in the Amazon Basin. Catena 71: 340-356.

Hickin E. 1978. Mean flow structure in meanders of the Squamish River, British Columbia. Canadian Journal of Earth Sciences 15: 1833-1849.

Hickin EJ. 1974. The development of meanders in natural river-channels. American Journal of Science 274: 414-442.

Hooke J.M. 1984. Change in river meanders: a review of techniques and results of analyses. Progress in Physical Geography 8: 473-508.

Hooke JM. 1987. Changes in meander morphology. In International Geomorphology 1986, Gardiner V (ed.). Wiley: Chichester; 591-609.

Hooke JM. 1995. River channel adjustment to meander cutoffs on the River Bollin and River Dane, northwest England. Geomorphology 14: 235-253.

Hooke JM. 1997. Styles of channel change. In River engineering and management, Thorne CR, Hey RD, Newson MD (eds.). John Wiley \& Sons: Chichester; 237-268.

Hooke JM. 2003. River meander behaviour and instability: a framework for analysis. Transactions of the Institute of British Geographers 28: 238-253.

Hooke JM. 2004. Cutoffs galore!: occurrence and causes of multiple cutoffs on a meandering river. Geomorphology 61: 225-238. 
737 Hooke JM, Yorke L. 2010. Rates, distributions and mechanisms of change in 738 meander morphology over decadal timescales, River Dane, UK. Earth

739 Surface Processes and Landforms 35: 1601-1614.

740 Howard AD. 1992. Modeling channel migration and floodplain sedimentation in meandering streams. In Lowland floodplain rivers: geomorphological 41.

Howard AD. 1996. Modelling channel evolution and floodplain morphology. In Floodplain Processes, Anderson MG, Walling DE, Bates PD (eds.). John Wiley \& Sons: Chichester; 15-62.

Howard AD, Knutson TR. 1984. Sufficient conditions for river meandering: a simulation approach. Water Resources Research 20: 1659-1667.

Huang HQ, Nanson GC. 1998. The influence of bank strength on channel geometry: An integrated analysis of some observations. Earth Surface Processes and Landforms 23: 865-876.

Hudson PF, Kesel RH. 2000. Channel migration and meander-bend curvature in the lower Mississippi River prior to major human modification. Geology 28: 531534.

Ikeda S, Parker G, Sawai K. 1981. Bend theory of river meanders .1. Linear development. Journal of Fluid Mechanics 112: 363-377.

Johannesson H, Parker G. 1989. Linear theory of river meanders. In River meandering, Ikeda S, Parker G (eds.). AGU: Washington; 181-214.

Julian JP, Torres R. 2006. Hydraulic erosion of cohesive river banks. Geomorphology 76: 193-206. 
761 Kolb CR. 1975. Geologic control of sand boils along Mississippi River levees. US

762 Army Engineer Waterways Experiment Station: Vicksburg.

763 Lancaster ST, Bras RL. 2002. A simple model of river meandering and its

764 comparison to natural channels. Hydrological Processes 16: 1-26.

765 Latrubesse EM, Restrepo JD. 2014. Sediment yield along the Andes: continental

766 budget, regional variations, and comparisons with other basins from orogenic

767 mountain belts. Geomorphology 216: 225-233.

768 Lauer JW, Parker G. 2008. Modeling framework for sediment deposition, storage,

769 and evacuation in the floodplain of a meandering river: Theory. Water

$770 \quad$ Resources Research 44: W04425.

771

772

Limaye ABS, Lamb MP. 2014. Numerical simulations of bedrock valley evolution by meandering rivers with variable bank material, Journal of Geophysical Research - Earth Surface doi: 10.1002/2013JF002997

Luchi R, Zolezzi G, Tubino M. 2011. Bend theory of river meanders with spatial width variations. Journal of Fluid Mechanics 681: 311-339.

Mackey SD, Bridge JS. 1995. Three-dimensional model of alluvial stratigraphy: Theory and application, Journal of Sedimentary Research B65: 7-31.

Motta D, Abad JD, Langendoen EJ, Garcia MH. 2012a. The effects of floodplain soil heterogeneity on meander planform shape. Water Resources Research 48: W09518.

Motta D, Abad JD, Langendoen EJ, Garcia MH. 2012b. A simplified 2D model for meander migration with physically-based bank evolution. Geomorphology 163-164: 10-25.

Nanson GC, Hickin EJ. 1983. Channel Migration and Incision on the Beatton River. Journal of Hydraulic Engineering 109: 327-337. 
786 Nanson GC, Hickin EJ. 1986. A statistical analysis of bank erosion and channel

787

788

789

790

791

792

793

794

795

796

797

798

799

800

801

802

803

804

805

806

807

808 migration in western Canada. Geological Society of America Bulletin 97: 497504.

Parker G, Shimizu Y, Wilkerson GV, Eke EC, Abad JD, Lauer JW, Paola C, Dietrich WE, Voller VR. 2011. A new framework for modeling the migration of meandering rivers. Earth Surface Processes and Landforms 36: 70-86.

Perucca E, Camporeale C, Ridolfi L. 2007. Significance of the riparian vegetation dynamics on meandering river morphodynamics. Water Resources Research 43: W03430.

Plafker G. 1964. Oriented lakes and lineaments of Northeastern Bolivia. Geological Society of America Bulletin 75: 503-522.

Posner AJ, Duan JG. 2012. Simulating river meandering processes using stochastic bank erosion coefficient. Geomorphology 163-164: 26-36.

Salo J, Kalliola R, Häkkinen I, Mäkinen Y, Niemelä P, Puhakka M, Coley PD. 1986. River dynamics and the diversity of Amazon lowland forest. Nature 322: 254258.

Schumm SA, Spitz WJ. 1996. Geological influences on the Lower Mississippi River and its alluvial valley. Engineering Geology 45: 245-261.

Seminara G. 2006. Meanders. Journal of Fluid Mechanics 554: 271-297.

Stolum H-H. 1996. River meandering as a self-organization process. Science 271: $1710-1713$.

Sun T, Meakin P, Jossang T, Schwarz K. 1996. A simulation model for meandering rivers. Water Resources Research 32: 2937-2954. 
809 van de Wiel MJ, Darby SE. 2007. A new model to analyse the impact of woody

810 riparian vegetation on the geotechnical stability of riverbanks. Earth Surface

$811 \quad$ Processes and Landforms 32: 2185-2198.

812 Ward JV, Tockner K, Arscott DB, Claret C. 2002. Riverine landscape diversity.

$813 \quad$ Freshwater Biology 47: 517-539.

814 Xu D, Bai Y, Ma J, Tan Y. 2011. Numerical investigation of long-term planform

815 dynamics and stability of river meandering on fluvial floodplains.

$816 \quad$ Geomorphology 132: 195-207.

817 Zolezzi G, Luchi R, Tubino M. 2012. Modeling morphodynamic processes in

818 meandering rivers with spatial width variations. Reviews of Geophysics 50:

$819 \quad$ RG4005.

820 Zolezzi G, Seminara G. 2001. Downstream and upstream influence in river

821 meandering. Part 1. General theory and application to overdeepening. Journal

822 of Fluid Mechanics 438: 183-211.

823

824 
825 Table 1: Aerial and satellite imagery used for GIS analysis of migration patterns. All 826 Landsat scenes are from Path 001, Row 069 and 070. Rectification errors (relative to 827 the year 2000 Landsat images or SRTM in 2000) are given for both tiles or combined 828 tiles where applicable.

\begin{tabular}{|c|c|c|c|}
\hline Date & Type of image & Resolution (pixel size) & Rectification RMSE \\
\hline 1960 & aerial & & $>30 \mathrm{~m}$ \\
\hline October 1975 & Landsat LM2 & $83 \mathrm{~m}$ & $>30 \mathrm{~m}$ \\
\hline August 1987 & Landsat LT5 & $30 \mathrm{~m}$ & $>30 \mathrm{~m}$ \\
\hline August 1993 & Landsat LT5 & $30 \mathrm{~m}$ & $>30 \mathrm{~m}$ \\
\hline July 1996 & Landsat LT5 & $30 \mathrm{~m}$ & $76.7 \mathrm{~m}$ \\
\hline August 1997 & Landsat LT5 & $30 \mathrm{~m}$ & $11.9-14.7 \mathrm{~m}$ \\
\hline July 1998 & Landsat LT5 & $30 \mathrm{~m}$ & 18.0 \\
\hline July/ August 1999 & Landsat LE7 & $30 \mathrm{~m}$ & $7.5-11.7 \mathrm{~m}$ \\
\hline July/ August 2000 & Landsat LE7 & $30 \mathrm{~m}$ & $\begin{array}{l}8.8 \text { - } 9.3 \mathrm{~m} \text { (relative } \\
\text { to SRTM) }\end{array}$ \\
\hline June/ August 2001 & Landsat LE7 & $30 \mathrm{~m}$ & $9.2-18.4 m$ \\
\hline August 2003 & Landsat LT5 & $30 \mathrm{~m}$ & $8.2-15.6 m$ \\
\hline September 2004 & Landsat LT5 & $30 \mathrm{~m}$ & $8.2-15.6 m$ \\
\hline September 2005 & Landsat LT5 & $30 \mathrm{~m}$ & $8.2-15.6 m$ \\
\hline July 2006 & Landsat LT5 & $30 \mathrm{~m}$ & $8.2-15.6 m$ \\
\hline August 2007 & Landsat LT5 & $30 \mathrm{~m}$ & $8.2-15.6 m$ \\
\hline August 2008 & Landsat LT5 & $30 \mathrm{~m}$ & $8.2-15.6 m$ \\
\hline August 2009 & Landsat LT5 & $30 \mathrm{~m}$ & $8.2-15.6 m$ \\
\hline May 2010 & Landsat LT5 & $30 \mathrm{~m}$ & $6.8-7.3 \mathrm{~m}$ \\
\hline May/ June 2011 & Landsat LT5 & $30 \mathrm{~m}$ & $8.2-15.6 m$ \\
\hline
\end{tabular}




\section{Figure Captions}

831 Figure 1: a) Location of the Rio Beni, northeastern Bolivia; b) Rio Beni study reach

832 showing sub-reach boundaries and areas used to illustrate channel dynamics in

833 figures 6, 8 and 12. The background Landsat TM imagery was taken during the dry

834 season 2011.

835 Figure 2: Dominant styles of meander bend migration along the study reach: a)

836 Compounding; b) Expansion; c) Extension; d) Lateral displacement; e) Rotation; and

837 f) Longitudinal translation. Adapted from Hooke (1984). The red outline shows the

838 bank lines some time before the Landsat image was taken.

839 Figure 3: Typical bank sections along the study reach: a) Stable cutbank consisting

840 of clay-rich material at Bend 72 ; b) Bank composed of silty, highly erodible

841 sediments, with evidence of vertical layering.

842 Figure 4: Mean migration rates of bends of the Rio Beni between 1960 and 2011 (95

$843 \%$ confidence intervals shown as error bars). Bends are classified by the substrate or

844 the morphological feature into which they are migrating: banks composed of mixed-

845 sized sediments, clay-rich banks, silty and sandy point bar (and counter point bar)

846 deposits, active oxbow lakes, and former channels infilled with mixed-sized

847 sediments.

848 Figure 5: Proportion of bends within the 19 sub-reaches experiencing different styles

849 of migration between 1960 and 2011. Sub-reaches 1, 3-5, 7, 12 and 15 are

850 dominated by clay-rich banks.

851 Figure 6: Typical sequence of channel migration influenced by clay-rich banks

852 between bends 13 and 18 (in sub-reach 4) over the periods: a) 1975-1987; b) 1987- 
853 1993; and c) 1993-1996. Landsat image dates correspond to the end of each time

854 period while banklines shown in red represent the start of the time period in each

855 panel. The presence of resistant clay-rich cutbanks in bend 13, 14 and 18 (marked

856 orange in c) limit rates of bend migration and lead to up-valley skewing of mature

857 bends, such as bend 14. Flow direction is indicated by the arrow.

858 Figure 7: Changes over time in the length of straight channel segments (identified in

859 the key by the sub-reach number in which they are located), illustrating the gradual

860 down-valley lengthening that occurs over multiple decades downstream of clay-rich

861 banks. Typically these segments lengthen due to down-valley translation, increase in

862 bend wavelength and cutoff of bends downstream (solid lines), but contact with other

863 clay-rich banks can lead to the development of perturbations and thus termination of

864 the lengthening process (dashed lines). This process is also illustrated in Fig. $8 \mathrm{e}$ and

865 8f. Each line represents a single channel segment.

866 Figure 8: Migration of the Rio Beni between bends 34 and 44 over the periods: a)

867 1987-1993; b) 1993-1998; c) 1998-2001; d) 2001-2005; e) 2005-2011, and f) 2011-

868 2013. Landsat image dates correspond to the end of each time period while

869 banklines shown in red represent the start of the time period in each panel. The

870 channel in this location (sub-reach 7) straightens between 1998 and 2005, following

871 a series of cutoffs. Flow direction is indicated by an arrow and relevant bend

872 numbers are given. Exposed clay-rich banks were found at bend 35 and 40 (marked

873 orange in e and f).

874 Figure 9: Frequency distribution of channel curvature at sub-reaches that are

875 dominated by clay-rich banks (sub-reaches 1, 3-5, 7, 12 and 15) compared with the

876 remaining sub-reaches with few clay-rich banks. 
877 Figure 10: Mean centerline migration rates for the 19 sub-reaches along the Rio Beni 878 over four periods between 1960 and 2011. Symbols indicate the proportion of the 879 channel in each sub-reach experiencing mean migration rates above and below 880 threshold values $\left(5 \mathrm{ma}^{-1}\right.$ and $50 \mathrm{ma}^{-1}$, respectively). Arrows at the top of the image 881 indicate the occurrence of chute (grey) and neck (black) cutoffs.

882 Figure 11: Mean channel sinuosity for the 19 sub-reaches along the Rio Beni at five 883 points in time between 1960 and 2011.

884 Figure 12: Migration of the Rio Beni between bends 18 and 29 over the periods: a) 885 1993-1996; b) 1996-2001; c) 2001-2003; d) 2003-2009; and e) 2009-2011. Landsat image dates correspond to the end of each time period while banklines shown in red represent the start of the time period in each panel. Flow direction is indicated by an arrow and relevant bend numbers are given. Exposed clay-rich banks (marked orange in e) were found at bend 18, 20, 22, 24, 25, 26 and 29.

Figure 13: Time series of channel sinuosity for three numerical model simulations in which the dependence of bank erodibility on grain size composition is altered by 892 changing the value of $k$ in equation (2).

Figure 14: Frequency distributions of channel curvature for simulations in which bank erodibility is constant $(k=0)$ and bank erodibility varies as a function of grain size 895 composition $(k=3)$.

Figure 15: Spatial patterns of the fraction of fine sediment in the floodplain and the meandering channel position (at two instants in time) during model simulations in which bank erodibility is constant (upper panel; $k=0$ ) and bank erodibility varies as a 899 function of grain size composition (lower panel; $k=3$ ). 
900 Figure 16: Channel centre lines between 1960 and 2011 in the upper study reach

901 (sub-reaches 1-8) with arrows marking bends with clay-rich banks (orange lines).

902 These bends are relatively immobile over $>50$ years and act as fixed 'hinges'

903 between more mobile reaches (see text). Flow is from left to right (in order A-B-C). 


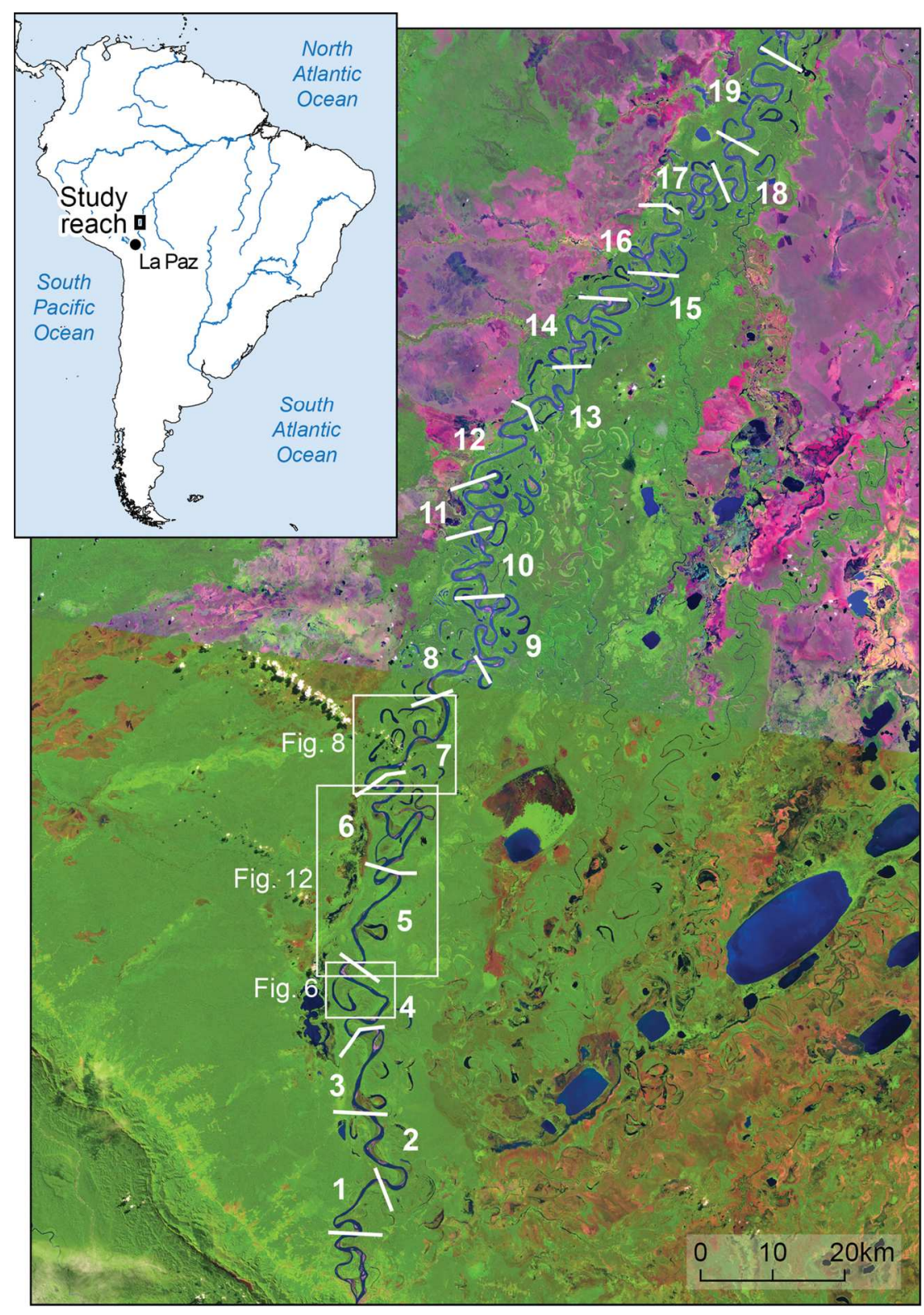

Figure 1: a) Location of the Rio Beni, northeastern Bolivia; b) Rio Beni study reach showing sub-reach boundaries and areas used to illustrate channel dynamics in figures 6, 8 and 12. The background Landsat TM imagery was taken during the dry season 2011. $119 \times 170 \mathrm{~mm}(300 \times 300 \mathrm{DPI})$ 
a)

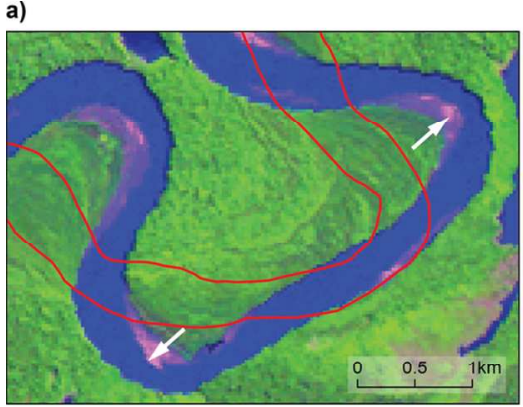

d)

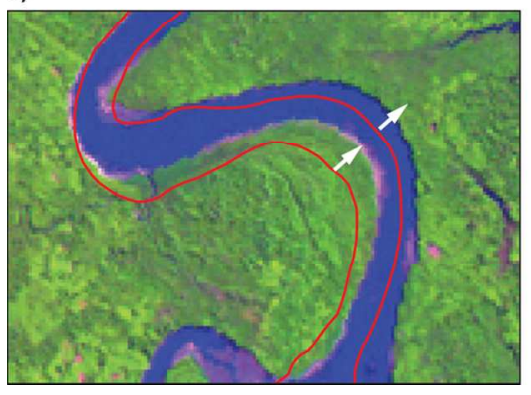

b)

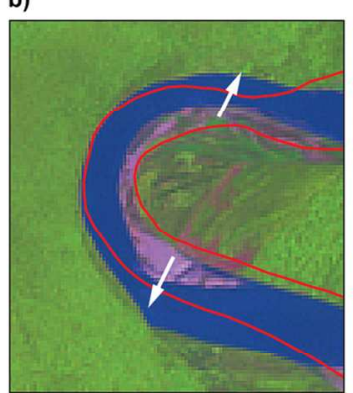

e)

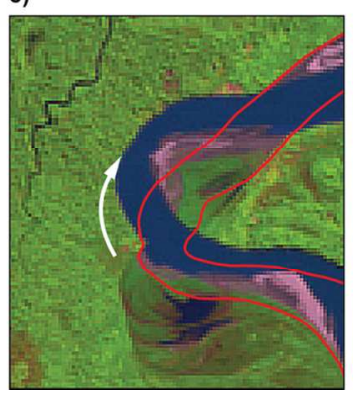

c)

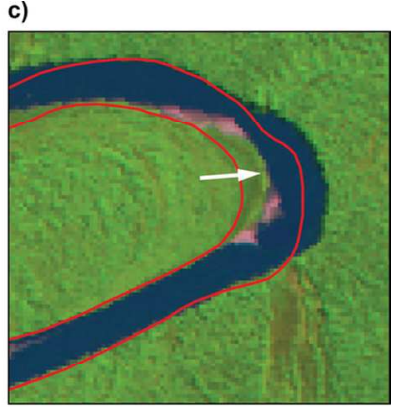

f)

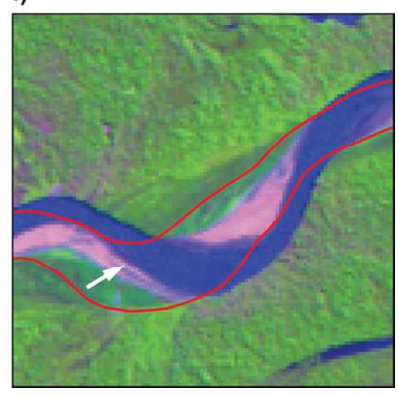

Figure 2: Dominant styles of meander bend migration along the study reach: a) Compounding; b) Expansion; c) Extension; d) Lateral displacement; e) Rotation; and f) Longitudinal translation. Adapted from Hooke (1984). The red outline shows the bank lines some time before the Landsat image was taken. $114 \times 74 \mathrm{~mm}(300 \times 300$ DPI $)$ 
a)

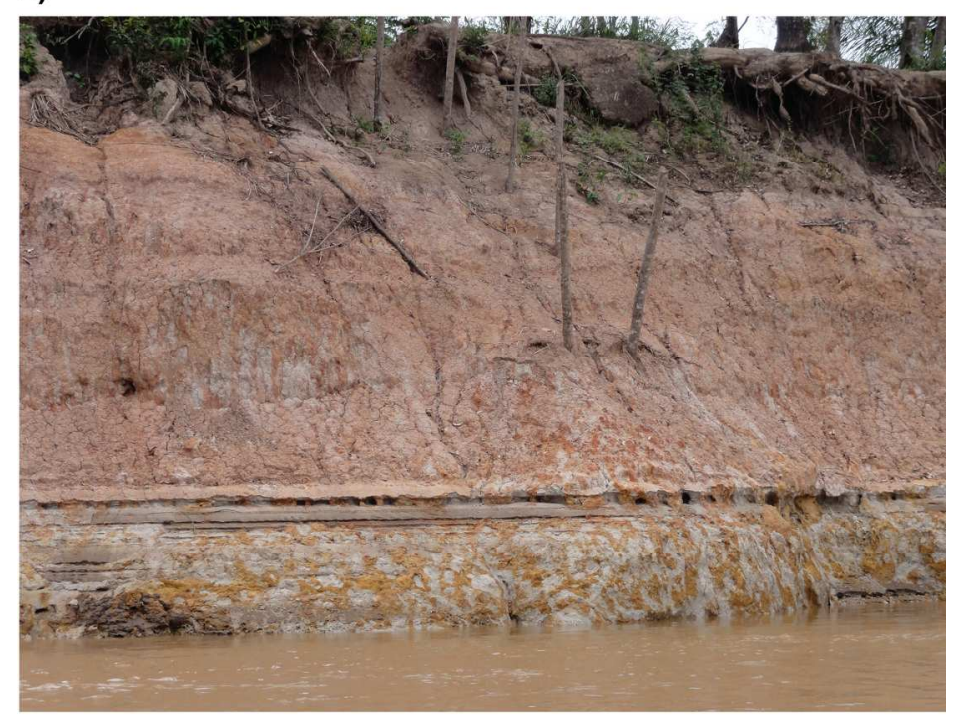

b)

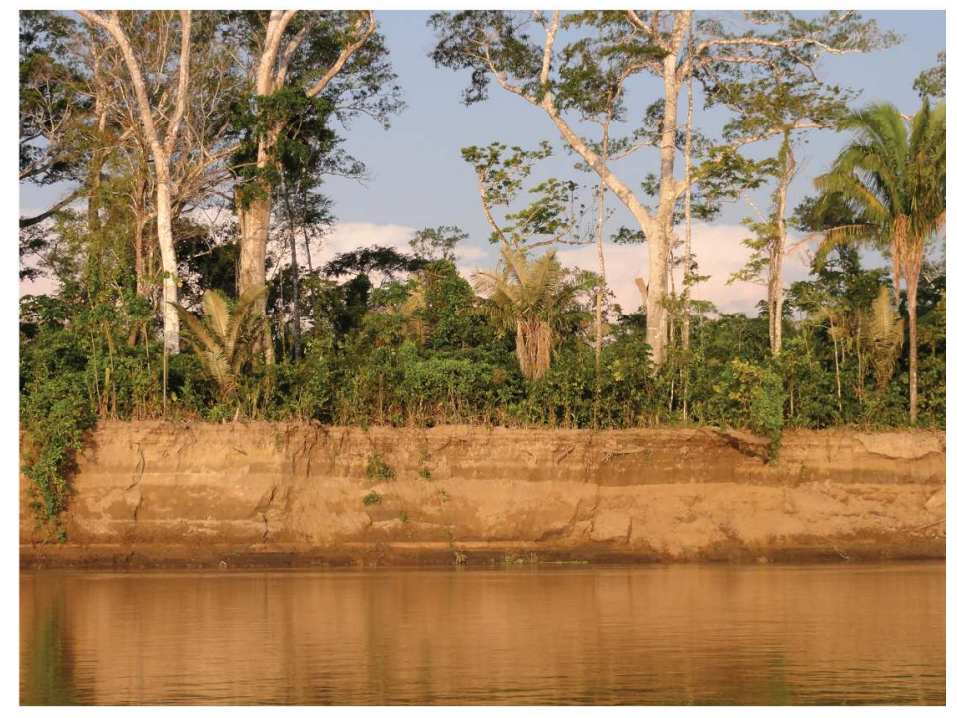

Figure 3: Typical bank sections along the study reach: a) Stable cutbank consisting of clay-rich material at Bend 72 ; b) Bank composed of silty, highly erodible sediments, with evidence of vertical layering. $141 \times 237 \mathrm{~mm}(300 \times 300 \mathrm{DPI})$ 
Figure 4: Mean migration rates of bends of the Rio Beni between 1960 and 2011 (95\% confidence intervals shown as error bars). Bends are classified by the substrate or the morphological feature into which they are migrating: banks composed of mixed-sized sediments, clay-rich banks, silty and sandy point bar (and counter point bar) deposits, active oxbow lakes, and former channels infilled with mixed sediments. $54 \times 34 \mathrm{~mm}(300 \times 300 \mathrm{DPI})$ 


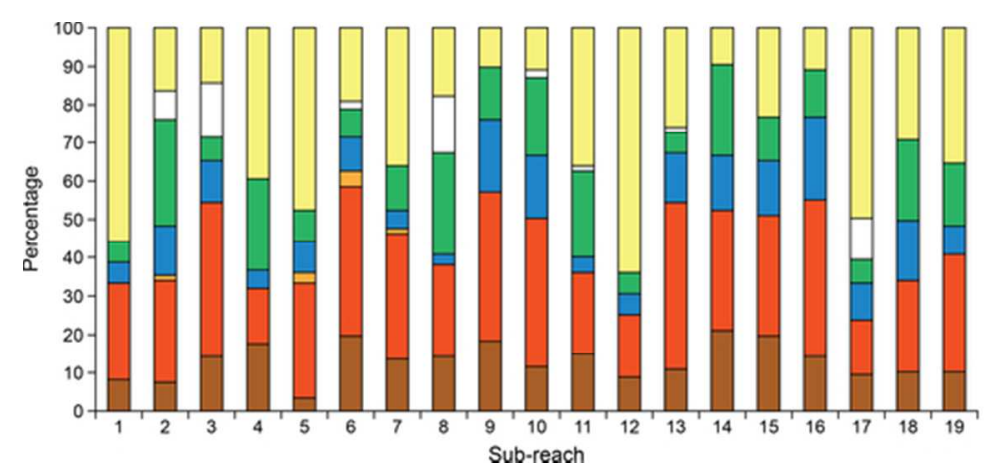

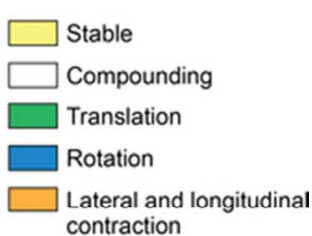
contraction

$\square$ Extension and lateral displacement

$\square$ Expansion

Figure 5: Proportion of bends within the 19 sub-reaches experiencing different styles of migration between 1960 and 2011. Sub-reaches $1,3-5,7,12$ and 15 are dominated by clay-rich banks. $59 \times 20 \mathrm{~mm}(300 \times 300 \mathrm{DPI})$ 
a)

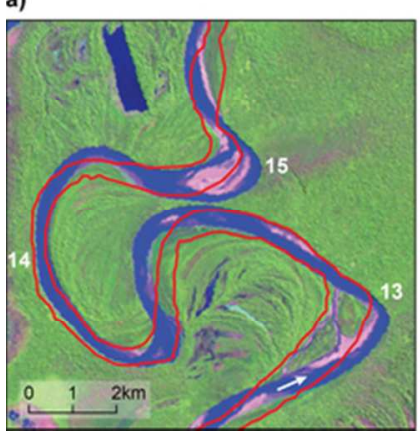

b)

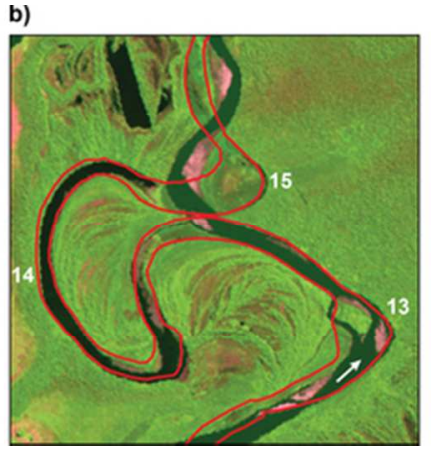

c)

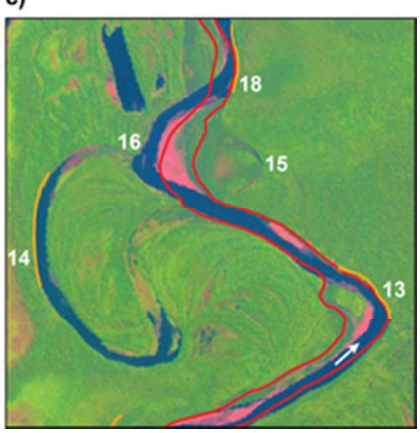

Figure 6: Typical sequence of channel migration influenced by clay-rich banks between bends 13 and 18 (in sub-reach 4) over the periods: a) 1975-1987; b) 1987-1993; and c) 1993-1996. Landsat image dates correspond to the end of each time period while banklines shown in red represent the start of the time period in each panel. The presence of resistant clay-rich cutbanks in bend 13, 14 and 18 (marked orange in c) limit rates of bend migration and lead to up-valley skewing of mature bends, such as bend 14 . Flow direction is indicated by the arrow. $59 \times 19 \mathrm{~mm}(300 \times 300 \mathrm{DPI})$ 


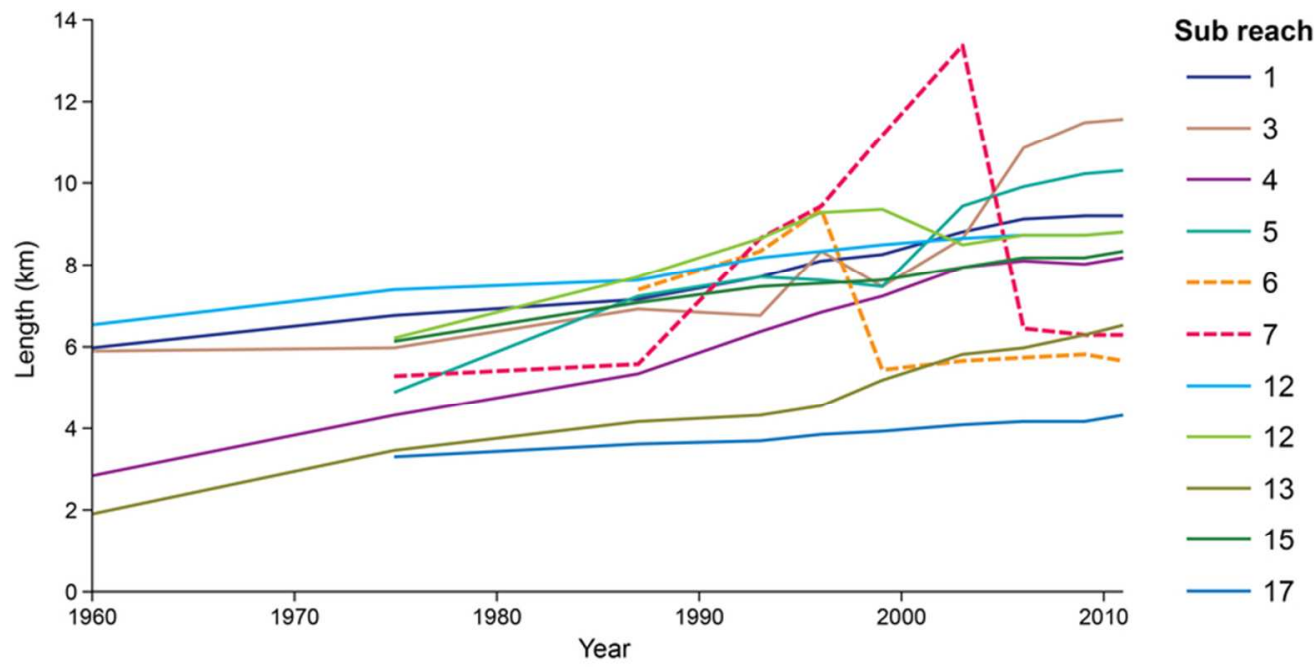

Figure 7: Changes over time in the length of straight channel segments (identified in the key by the subreach number in which they are located), illustrating the gradual down-valley lengthening that occurs over multiple decades downstream of clay-rich banks. Typically these segments lengthen due to down-valley translation, increase in bend wavelength and cutoff of bends downstream (solid lines), but contact with other clay-rich banks can lead to the development of perturbations and thus termination of the lengthening process (dashed lines). This process is also illustrated in Fig. $8 \mathrm{e}$ and $8 \mathrm{f}$. Each line represents a single channel segment.

$72 \times 36 \mathrm{~mm}(300 \times 300$ DPI $)$ 
a)

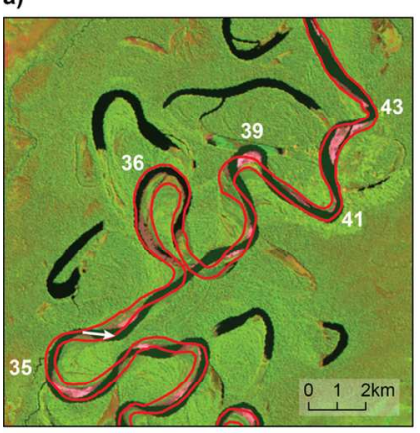

d)

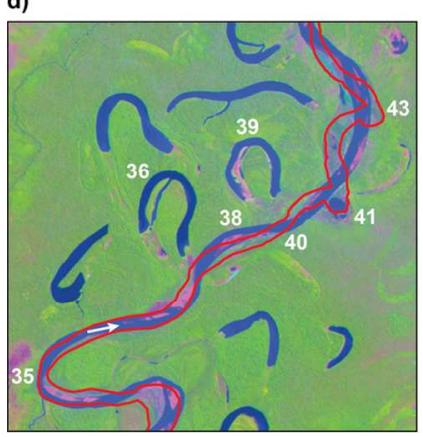

b)

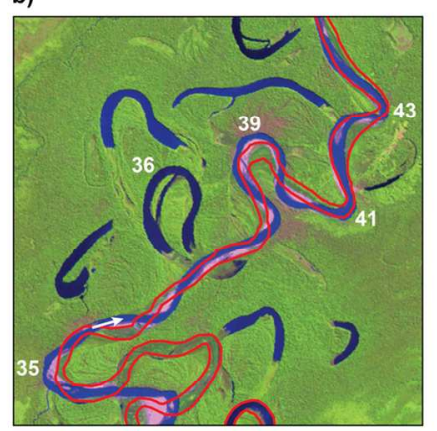

e)

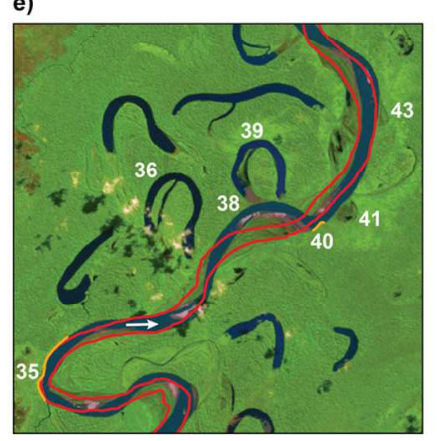

c)

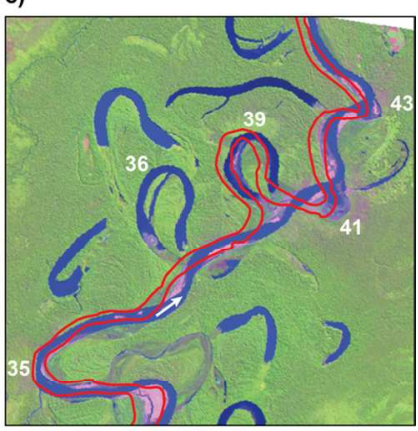

f)

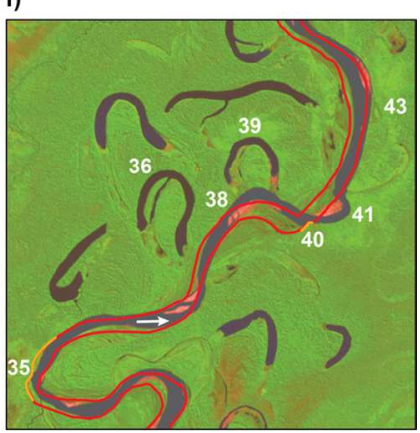

Figure 8: Migration of the Rio Beni between bends 34 and 44 over the periods: a) 1987-1993; b) 19931998 ; c) 1998-2001; d) 2001-2005; e) 2005-2011, and f) 2011-2013. Landsat image dates correspond to the end of each time period while banklines shown in red represent the start of the time period in each panel. The channel in this location (sub-reach 7) straightens between 1998 and 2005, following a series of cutoffs. Flow direction is indicated by an arrow and relevant bend numbers are given. Exposed clay-rich banks were found at bend 35 and 40 (marked orange in e and $\mathrm{f}$ ). $123 \times 87 \mathrm{~mm}(300 \times 300 \mathrm{DPI})$ 
1

2

3

4

5

6

7

8

9

10

11

12

13

14

15

16

17

18

19

20

21

22

23

24

25

26

27

28

29

30

31

32

33

34

35

36

37

38

39

40

41

42

43

44

45

46

47

48

49

50

51

52

53

54

55

56

57

58

59

60

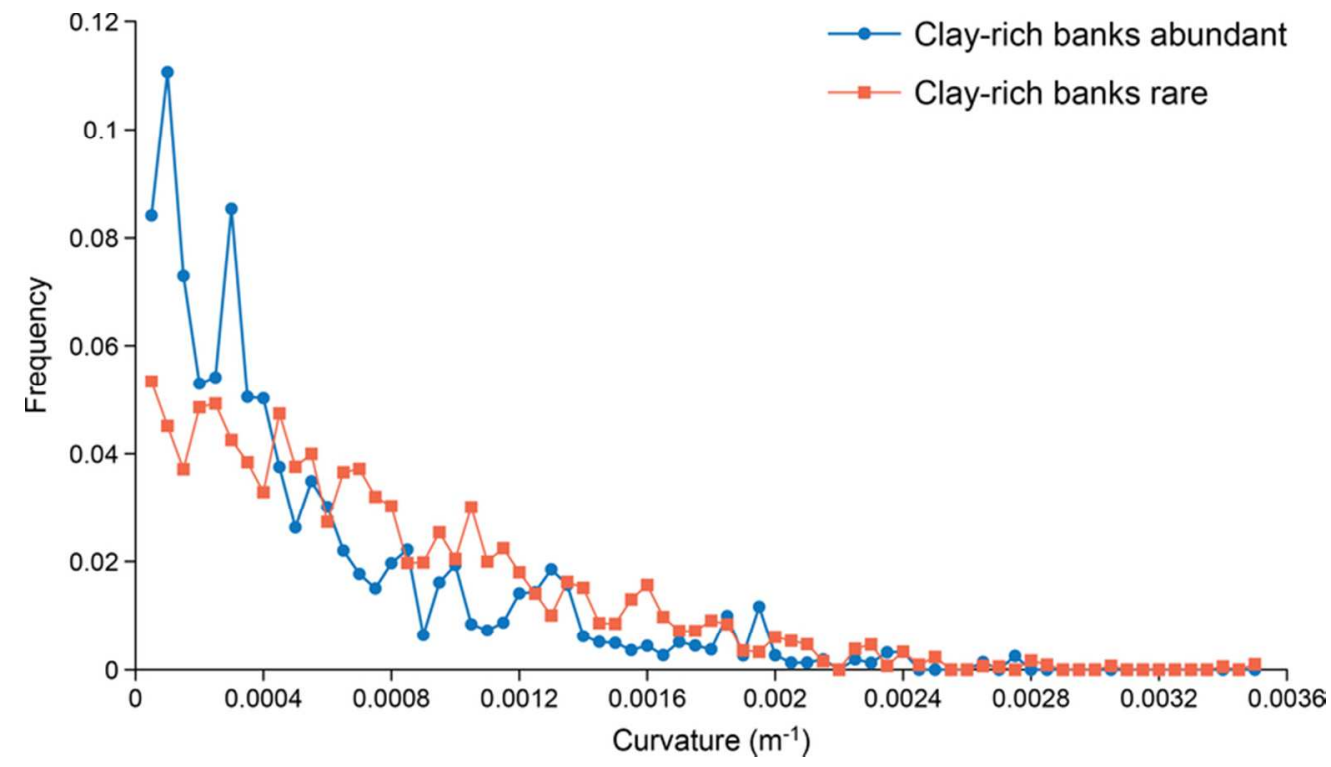

Figure 9: Frequency distribution of channel curvature at sub-reaches that are dominated by clay-rich banks (sub-reaches 1, 3-5, 7, 12 and 15) compared with the remaining sub-reaches with few clay-rich banks.

$71 \times 41 \mathrm{~mm}$ (300 x 300 DPI) 

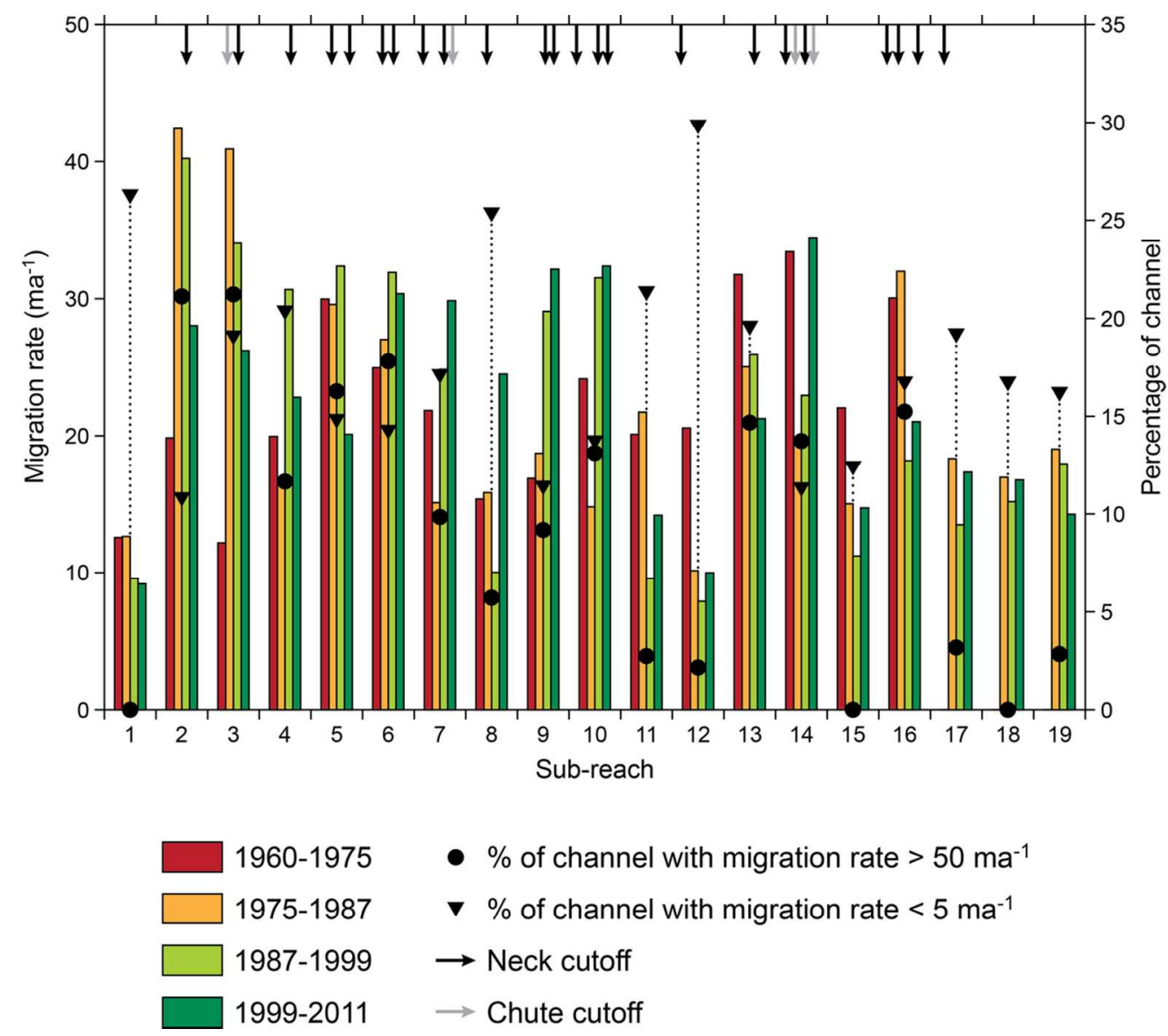

Figure 10: Mean centerline migration rates for the 19 sub-reaches along the Rio Beni over four periods between 1960 and 2011. Symbols indicate the proportion of the channel in each sub-reach experiencing mean migration rates above and below threshold values ( 5 ma-1 and 50 ma-1, respectively). Arrows at the top of the image indicate the occurrence of chute (grey) and neck (black) cutoffs. $110 \times 98 \mathrm{~mm}(300 \times 300$ DPI $)$ 


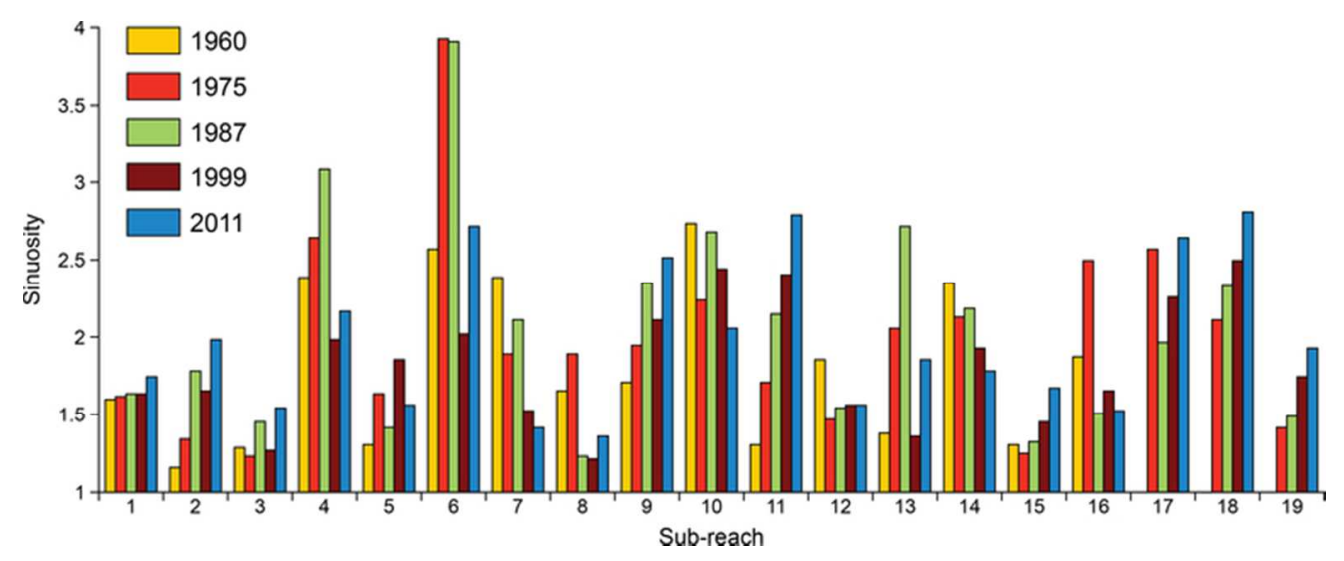

Figure 11: Mean channel sinuosity for the 19 sub-reaches along the Rio Beni at five points in time between 1960 and 2011.

$65 \times 26 \mathrm{~mm}(300 \times 300$ DPI $)$ 


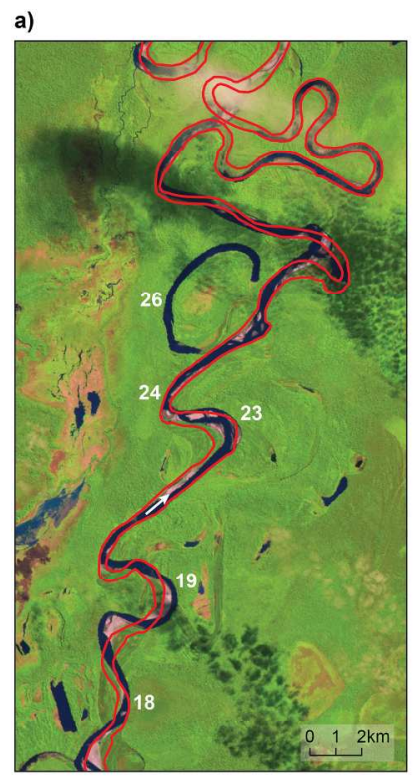

b)

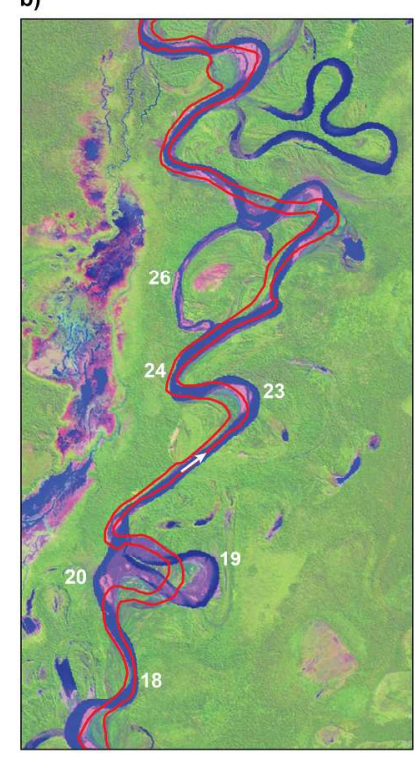

d)

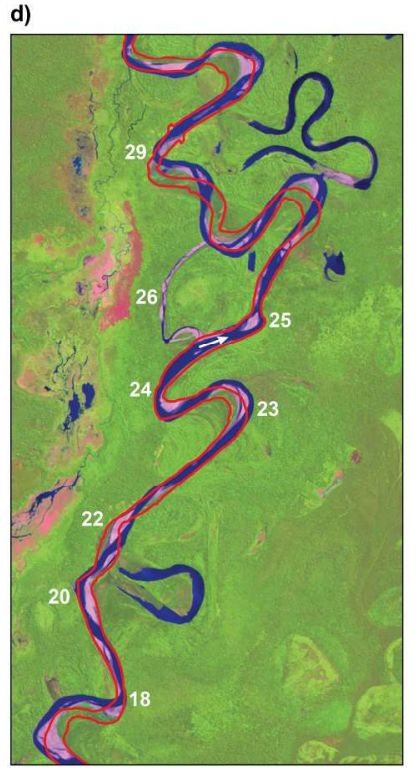

e)

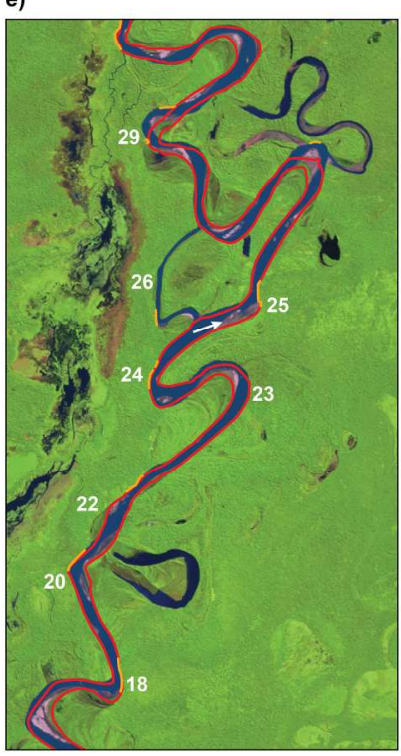

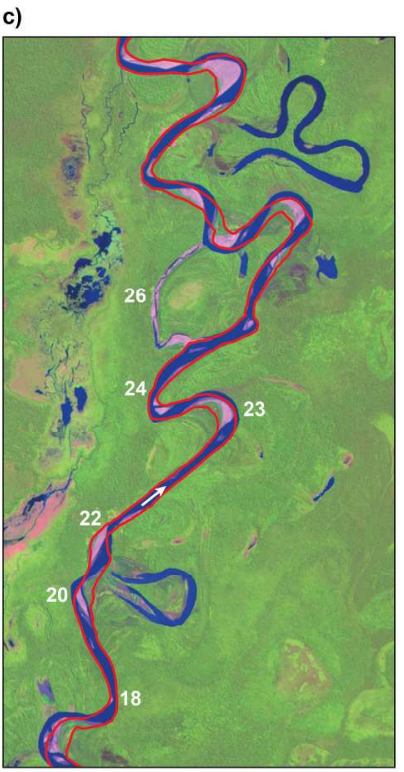

Figure 12: Migration of the Rio Beni between bends 18 and 29 over the periods: a) 1993-1996; b) 19962001 ; c) 2001-2003; d) 2003-2009; and e) 2009-2011. Landsat image dates correspond to the end of each time period while banklines shown in red represent the start of the time period in each panel. Flow direction is indicated by an arrow and relevant bend numbers are given. Exposed clay-rich banks (marked orange in

e) were found at bend 18, 20, 22, 24, 25, 26 and 29. $218 \times 272 \mathrm{~mm}(300 \times 300 \mathrm{DPI})$ 
Figure 13: Time series of channel sinuosity for three numerical model simulations in which the dependence of bank erodibility on grain size composition is altered by changing the value of $\mathrm{k}$ in equation (2). $73 \times 42 \mathrm{~mm}(300 \times 300 \mathrm{DPI})$ 


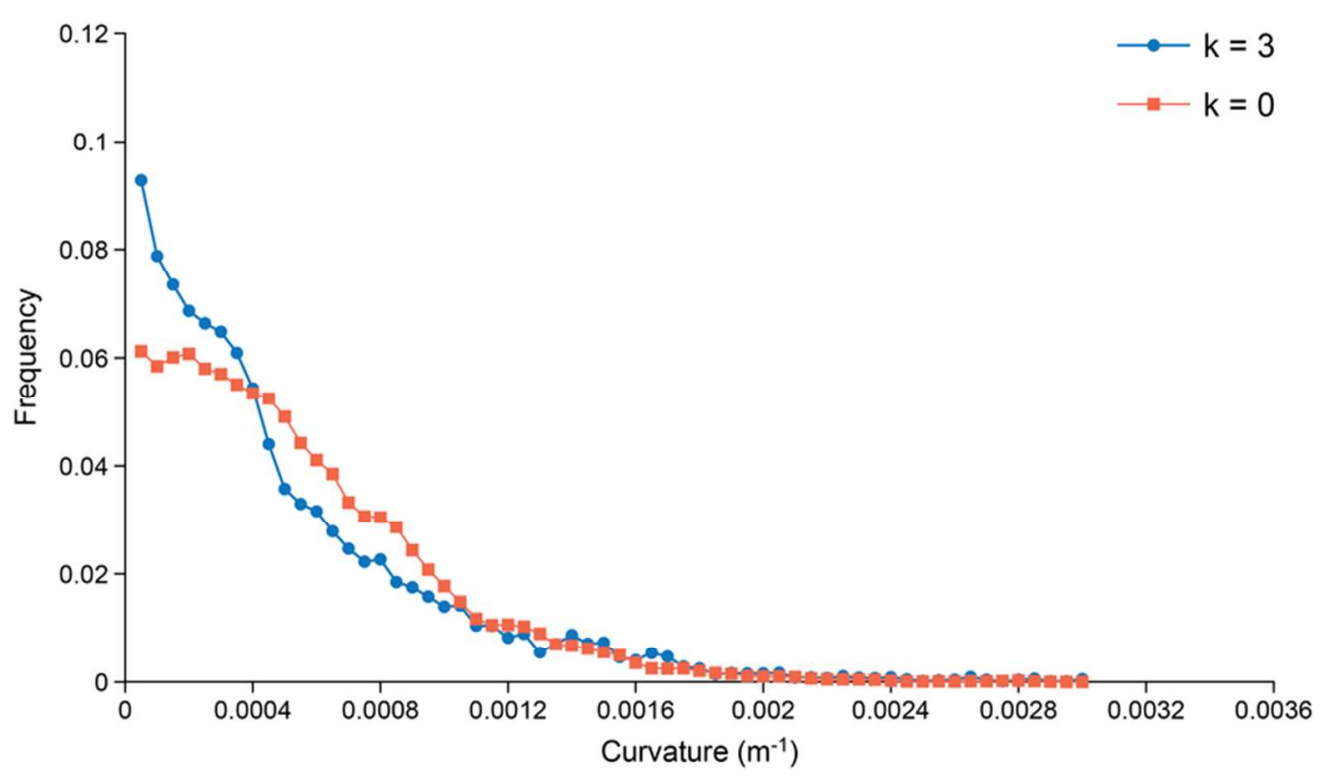

Figure 14: Frequency distributions of channel curvature for simulations in which bank erodibility is constant $(\mathrm{k}=0)$ and bank erodibility varies as a function of grain size composition $(\mathrm{k}=3)$. $72 \times 41 \mathrm{~mm}(300 \times 300 \mathrm{DPI})$ 

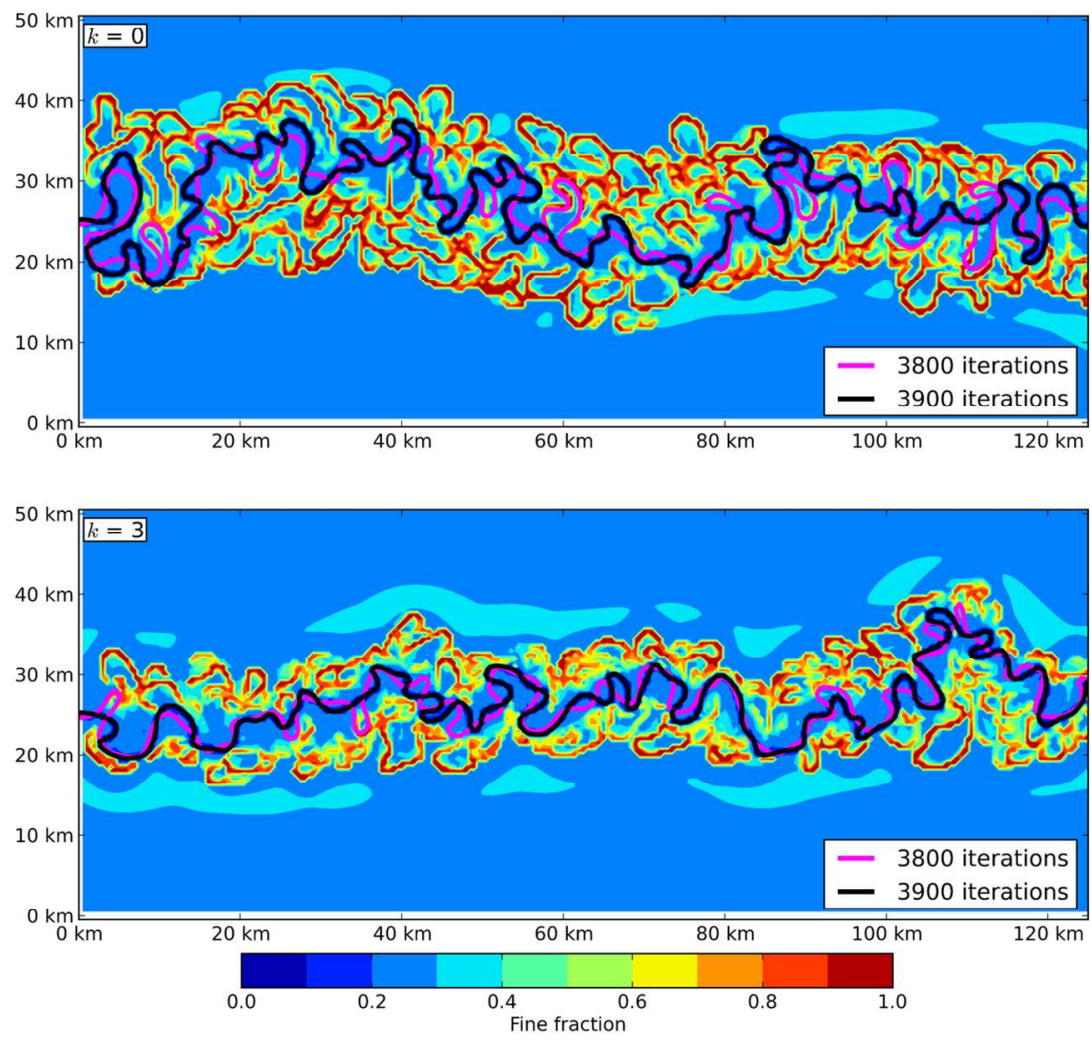

Figure 15: Spatial patterns of the fraction of fine sediment in the floodplain and the meandering channel position (at two instants in time) during model simulations in which bank erodibility is constant (upper panel; $k=0$ ) and bank erodibility varies as a function of grain size composition (lower panel; $k=3$ ). $127 \times 110 \mathrm{~mm}(300 \times 300$ DPI) 
Figure 16: Channel centre lines between 1960 and 2011 in the upper study reach (sub-reaches 1-8) with arrows marking bends with clay-rich banks (orange lines). These bends are relatively immobile over $>50$ years and act as fixed 'hinges' between more mobile reaches (see text). Flow is from left to right (in order A-B-C).

$107 \times 74 \mathrm{~mm}(300 \times 300 \mathrm{DPI})$ 